\title{
Export fluxes in a naturally iron-fertilized area of the Southern Ocean - Part 1: Seasonal dynamics of particulate organic carbon export from a moored sediment trap
}

\author{
M. Rembauville ${ }^{1,2}$, I. Salter ${ }^{1,2,3}$, N. Leblond ${ }^{4,5}$, A. Gueneugues ${ }^{1,2}$, and S. Blain ${ }^{1,2}$ \\ ${ }^{1}$ Sorbonne Universités, UPMC Univ Paris 06, UMR7621, LOMIC, Observatoire Océanologique, Banyuls-sur-Mer, France \\ ${ }^{2}$ CNRS, UMR7621, LOMIC, Observatoire Océanologique, Banyuls-sur-Mer, France \\ ${ }^{3}$ Alfred Wegener Institute for Polar and Marine Research, Bremerhaven, Germany \\ ${ }^{4}$ Sorbonne Universités, UPMC Univ Paris 06, LOV, UMR7093, Observatoire Océanologique, Villefranche-sur-Mer, France \\ ${ }^{5}$ CNRS-INSU, LOV, UMR7093, Observatoire Océanologique, Villefranche-sur-Mer, France
}

Correspondence to: M. Rembauville (rembauville@obs-banyuls.fr)

Received: 7 November 2014 - Published in Biogeosciences Discuss.: 10 December 2014

Revised: 27 April 2015 - Accepted: 1 May 2015 - Published: 2 June 2015

\begin{abstract}
A sediment trap moored in the naturally ironfertilized Kerguelen Plateau in the Southern Ocean provided an annual record of particulate organic carbon and nitrogen fluxes at $289 \mathrm{~m}$. At the trap deployment depth, current speeds were typically low ( $\sim 10 \mathrm{~cm} \mathrm{~s}^{-1}$ ) and primarily tidaldriven (M2 tidal component). Although advection was weak, the sediment trap may have been subject to hydrodynamical and biological (swimmer feeding on trap funnel) biases. Particulate organic carbon (POC) flux was generally low $\left(<0.5 \mathrm{mmol} \mathrm{m}^{-2} \mathrm{~d}^{-1}\right)$, although two episodic export events ( $<14$ days) of $1.5 \mathrm{mmol} \mathrm{m}^{-2} \mathrm{~d}^{-1}$ were recorded. These increases in flux occurred with a 1-month time lag from peaks in surface chlorophyll and together accounted for approximately $40 \%$ of the annual flux budget. The annual POC flux of $98.2 \pm 4.4 \mathrm{mmol} \mathrm{m}^{-2} \mathrm{yr}^{-1}$ was low considering the shallow deployment depth but comparable to independent estimates made at similar depths $(\sim 300 \mathrm{~m})$ over the plateau, and to deep-ocean $(>2 \mathrm{~km}$ ) fluxes measured from similarly productive iron-fertilized blooms. Although undertrapping cannot be excluded in shallow moored sediment trap deployment, we hypothesize that grazing pressure, including mesozooplankton and mesopelagic fishes, may be responsible for the low POC flux beneath the base of the winter mixed layer. The importance of plankton community structure in controlling the temporal variability of export fluxes is addressed in a companion paper.
\end{abstract}

\section{Introduction}

The biological carbon pump is defined as the downward transfer of biologically fixed carbon from the ocean surface to the ocean interior (Volk and Hoffert, 1985). Global estimates of particulate organic carbon (POC) export cluster between $5 \mathrm{PgC} \mathrm{yr}^{-1}$ (Moore et al., 2004; Lutz et al., 2007; Honjo et al., 2008; Henson et al., 2011; Lima et al., 2014) and $10 \mathrm{Pg} \mathrm{C} \mathrm{yr}^{-1}$ (Laws et al., 2000; Schlitzer, 2004; Gehlen et al., 2006; Boyd and Trull, 2007; Dunne et al., 2007; Laws et al., 2011). The physical transfer of dissolved inorganic carbon to the ocean interior during subduction of water masses is 2 orders of magnitude higher (> $250 \mathrm{Pg} \mathrm{C} \mathrm{yr}^{-1}$; Karleskind et al., 2011; Levy et al., 2013). The global ocean represents a net annual $\mathrm{CO}_{2}$ sink of $2.5 \mathrm{Pg} \mathrm{Cyr}^{-1}$ (Le Quéré et al., 2013), slowing down the increase in the atmospheric $\mathrm{CO}_{2}$ concentration resulting from anthropogenic activity. Although the Southern Ocean (south of $44^{\circ} \mathrm{S}$ ) plays a limited role in the net air-sea $\mathrm{CO}_{2}$ flux (Lenton et al., 2013), it is a key component of the global anthropogenic $\mathrm{CO}_{2}$ sink representing onethird the global oceanic sink $\left(\sim 1 \mathrm{Pg} \mathrm{Cyr}^{-1}\right)$ while covering $20 \%$ of its surface (Gruber et al., 2009). The solubility pump is considered to be the major component of this sink, whereas the biological carbon pump is considered to be inefficient in the Southern Ocean and sensitive to iron supply.

Following "the iron hypothesis" in the 1990s (Martin, 1990), iron limitation of high-nutrient, low-chlorophyll (HNLC) areas, including the Southern Ocean, has been tested 
in bottle experiments (de Baar et al., 1990) and through in situ artificial fertilization experiments (de Baar et al., 2005; Boyd et al., 2007). Results from these experiments are numerous and essentially highlight that the lack of iron limits macronutrient (N, P, Si) utilization (Boyd et al., 2005; Hiscock and Millero, 2005) and primary production (Landry et al., 2000; Gall et al., 2001; Coale et al., 2004) in these vast HNLC areas of the Southern Ocean. Due to a large macronutrient repository, the biological carbon pump in the Southern Ocean is considered to be inefficient in its capacity to transfer atmospheric carbon to the ocean interior (Sarmiento and Gruber, 2006). In the context of micronutrient limitation, sites enriched in iron by natural processes have also been studied and include the Kerguelen Islands (Blain et al., 2001, 2007), the Crozet Islands (Pollard et al., 2007), the Scotia Sea (Tarling et al., 2012) and the Drake Passage (Measures et al., 2013). Enhanced primary producer biomass in association with natural iron supply (Korb and Whitehouse, 2004; Seeyave et al., 2007; Lefèvre et al., 2008) strongly support trace-metal limitation. Furthermore, indirect seasonal budgets constructed from studies of naturally fertilized systems have been capable of demonstrating an increase in the strength of the biological carbon pump (Blain et al., 2007; Pollard et al., 2009), although strong discrepancies in carbon to iron sequestration efficiency exist between systems. To date, direct measurements of POC export over seasonal cycles from naturally fertilized blooms in the Southern Ocean are limited to the Crozet Plateau (Pollard et al., 2009; Salter et al., 2012). The HNLC Southern Ocean represents a region where changes in the strength of the biological pump may have played a role in the glacial-interglacial $\mathrm{CO}_{2}$ cycles (Bopp et al., 2003; Kohfeld et al., 2005) and have some significance to future anthropogenic $\mathrm{CO}_{2}$ uptake (Sarmiento and Le Quéré, 1996). In this context, additional studies that directly measure POC export from naturally iron-fertilized blooms in the Southern Ocean are necessary.

POC export can be estimated at short timescales (days to weeks) using the ${ }^{234} \mathrm{Th}$ proxy (Coale and Bruland, 1985; Buesseler et al., 2006; Savoye et al., 2006), by optical imaging of particles (e.g. Picheral et al., 2010, Jouandet et al., 2011) or by directly collecting particles into surface-tethered sediment traps (e.g. Maiti et al., 2013 for a compilation in the Southern Ocean) or neutrally buoyant sediment traps (e.g. Salter et al., 2007; Rynearson et al., 2013). Temporal variability of flux in the Southern Ocean precludes extrapolation of discrete measurements to estimate seasonal or annual carbon export. However, seasonal export of POC can be derived from biogeochemical budgets (Blain et al., 2007; Jouandet et al., 2011; Pollard et al., 2009) or be directly measured by moored sediment traps (e.g. Salter et al., 2012). Biogeochemical budgets are capable of integrating over large spatial and temporal scales but may incorporate certain assumptions and lack information about underlying mechanisms. Direct measurement by sediment traps rely on fewer assumptions but their performance is strongly related to prevailing hydrody- namic conditions (Buesseler et al., 2007a), which can be particularly problematic in the surface ocean. Measuring the hydrological conditions characterizing mooring deployments is therefore crucial to address issues surrounding the efficiency of sediment trap collection.

The ecological processes responsible for carbon export remain poorly characterized (Boyd and Trull, 2007). There is a strong requirement for quantitative analysis of the biological components of export to elucidate patterns in carbon and biomineral fluxes to the ocean interior (Francois et al., 2002; Salter et al., 2010; Henson et al., 2012; Le Moigne et al., 2012; Lima et al., 2014). Long-term deployment of moored sediment traps in areas of naturally iron-fertilized production, where significant macro- and micronutrient gradients seasonally structure plankton communities, can help to establish links between ecological succession and carbon export. For example, sediment traps around the Crozet Plateau (Pollard et al., 2009) identified the significance of Eucampia antarctica var. antarctica resting spores for carbon transfer to the deep ocean, large empty diatom frustules for $\mathrm{Si}$ : C export stoichiometry (Salter et al., 2012) and heterotrophic calcifiers for the carbonate counter pump (Salter et al., 2014).

The increase in primary production resulting from natural fertilization might not necessarily lead to significant increases in carbon export. The concept of "high-biomass, low-export" (HBLE) environments was first introduced in the Southern Ocean (Lam and Bishop, 2007). This concept is partly based on the idea that a strong grazer response to phytoplankton biomass leads to major fragmentation and remineralization of particles in the twilight zone, shallowing the remineralization horizon (Coale et al., 2004). In these environments, the efficient utilization and reprocessing of exported carbon by zooplankton leads to faecal-pelletdominated, low-POC fluxes (Ebersbach et al., 2011). A synthesis of short-term sediment trap deployments, ${ }^{234} \mathrm{Th}$ estimates of upper ocean POC export, and in situ primary production measurements in the Southern Ocean by Maiti et al. (2013) highlighted the inverse relationship between primary production and export efficiency, verifying the HBLE status of many productive areas in the Southern Ocean. The iron-fertilized bloom above the Kerguelen Plateau exhibits strong remineralization in the mixed layer compared to the mesopelagic (Jacquet et al., 2008) and high bacterial carbon demand (Obernosterer et al., 2008), features consistent with a HBLE regime. Moreover, an inverse relationship between export efficiency and zooplankton biomass in the Kerguelen Plateau region supports the key role of grazers in the HBLE scenario (Laurenceau-Cornec et al., 2015). Efficient grazer responses to phytoplankton biomass following artificial iron fertilization of HNLC regions also demonstrate increases in net community production that are not translated to an increase in export fluxes (Lam and Bishop, 2007; Tsuda et al., 2007; Martin et al., 2013; Batten and Gower, 2014).

POC flux attenuation with depth results from processes occurring in the euphotic layer (setting the particle export 
efficiency, Henson et al., 2012) and processes occurring in the twilight zone between the euphotic layer and $\sim 1000 \mathrm{~m}$ (Buesseler and Boyd, 2009), setting the transfer efficiency (Francois et al., 2002). These processes are mainly biologically driven (Boyd and Trull, 2007) and involve a large diversity of ecosystem components from bacteria (Rivkin and Legendre, 2001; Giering et al., 2014), protozooplankton (Barbeau et al., 1996), mesozooplankton (Dilling and Alldredge, 2000; Smetacek et al., 2004) and mesopelagic fishes (Davison et al., 2013; Hudson et al., 2014). The net effect of these processes is summarized in a power-law formulation of POC flux attenuation with depth proposed by Martin et al. (1987) that is still commonly used in data and model applications. The $b$ exponent in this formulation has been reported to range from 0.4 to 1.7 (Buesseler et al., 2007b; Lampitt et al., 2008; Henson et al., 2012) in the global ocean. Nevertheless, a change in the upper mesopelagic community structure (Lam et al., 2011) and, more precisely, an increasing contribution of mesozooplankton (Lam and Bishop, 2007; Ebersbach et al., 2011) could lead to a shift toward higher POC flux attenuation with depth.

In this paper, we provide the first annual description of the POC and PON export fluxes below the mixed layer within the naturally fertilized bloom of the Kerguelen Plateau, and we discuss the reliability of these measurements considering the hydrological and biological context. A companion paper (Rembauville et al., 2015) addresses our final aim: to identify the ecological vectors that explain the intensity and the stoichiometry of the fluxes.

\section{Material and methods}

\subsection{Trap deployment and mooring design}

As part of the KEOPS2 multidisciplinary programme, a mooring line was deployed at station A3 $\left(50^{\circ} 38.3 \mathrm{~S}\right.$ $72^{\circ} 02.6 \mathrm{E}$ ) in the Permanently Open Ocean Zone (POOZ), south of the polar front (PF; Fig. 1). The mooring line was instrumented with a Technicap PPS3 $\left(0.125 \mathrm{~m}^{2}\right.$ collecting area, 4.75 aspect ratio) sediment trap and inclinometer (NKE S2IP) at a depth of $289 \mathrm{~m}$ (seafloor depth $527 \mathrm{~m}$; Fig. 2). A conductivity-temperature-pressure (CTD) sensor (Sea-Bird SBE 37) and a current meter (Nortek Aquadopp) were placed on the mooring line $30 \mathrm{~m}$ beneath the sediment trap $(319 \mathrm{~m})$. The sediment trap collection period started on 21 October 2011 and continued until 7 September 2012. The sediment trap was composed of 12 rotating sample cups $(250 \mathrm{~mL})$ filled with a $5 \%$ formalin hypersaline solution buffered with sodium tetraborate at $\mathrm{pH}=8$. Rotation of the carousel was programmed to sample short intervals (10-14 days) between October and February to optimize the temporal resolution of export from the bloom, and long intervals (99 days) between February and September. All instruments had a $1 \mathrm{~h}$ recording interval. The current meter failed on 7 April 2012.

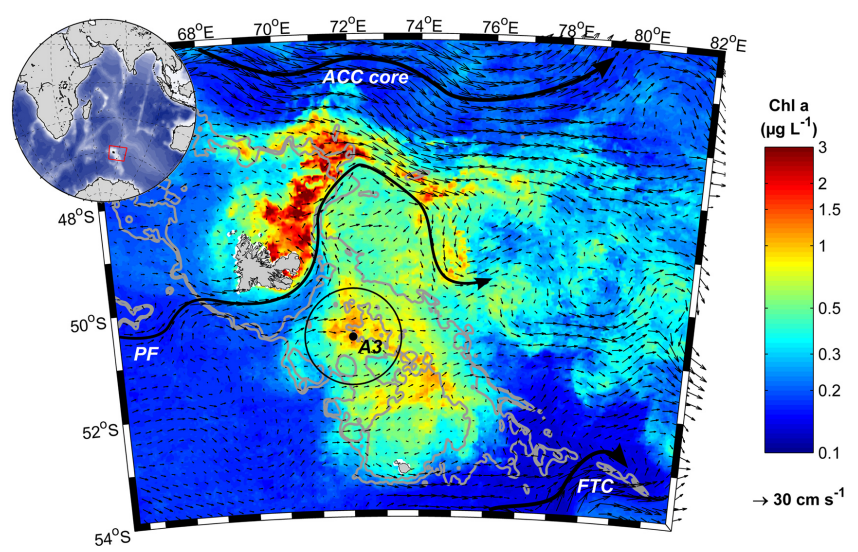

Figure 1. Localization of the Kerguelen Plateau in the Indian sector of the Southern Ocean and detailed map of the satellite-derived surface chlorophyll $a$ concentration (MODIS level 3 product) averaged over the sediment trap deployment period. Sediment trap location at station A3 is represented by a black dot, whereas the black circle represents the $100 \mathrm{~km}$ radius area used to average the surface chlorophyll $a$ time series. Arrows represent surface geostrophic circulation derived from the absolute dynamic topography (AVISO product). Positions of the Antarctic Circumpolar Current core (AAC core), the polar front (PF) and the Fawn Trough Current (FTC) are shown by thick black arrows. Grey lines are 500 and $1000 \mathrm{~m}$ isobaths.

\subsection{Surface chlorophyll data}

The MODIS AQUA level 3 (4 km grid resolution, 8-day averages) surface chlorophyll $a$ product was extracted from the NASA website (http://oceancolor.gsfc.nasa.gov/) for the sediment trap deployment period. An annual climatology of surface chlorophyll $a$ concentration, based on available satellite products (1997-2013), was calculated from the multisatellite GlobColour product. The GlobColour level 3 (case 1 waters, $4.63 \mathrm{~km}$ resolution, 8-day averages) product merging SeaWiFS, MODIS and MERIS data with GSM merging model (Maritorena and Siegel, 2005) was accessed via http://www.globcolour.info. Surface chlorophyll $a$ concentrations derived from GlobColour (climatology) and MODIS data (deployment year) were averaged across a $100 \mathrm{~km}$ radius centred on the sediment trap deployment location (Fig. 1).

\subsection{Time series analyses of hydrological parameters}

Fast Fourier transform (FFT) analysis was performed on the annual time series data obtained from the mooring, depth and potential density anomaly $\left(\sigma_{\theta}\right)$ that were derived from the CTD sensor. Significant peaks in the power spectrum were identified by comparison to red noise, a theoretical signal in which the relative variance decreases with increasing frequency (Gilman et al., 1963). The red noise signal was considered as a null hypothesis, and its power spectrum was scaled to the 99th percentile of $\chi^{2}$ probability. Power peaks higher than $99 \%$ red noise values were considered to be sta- 


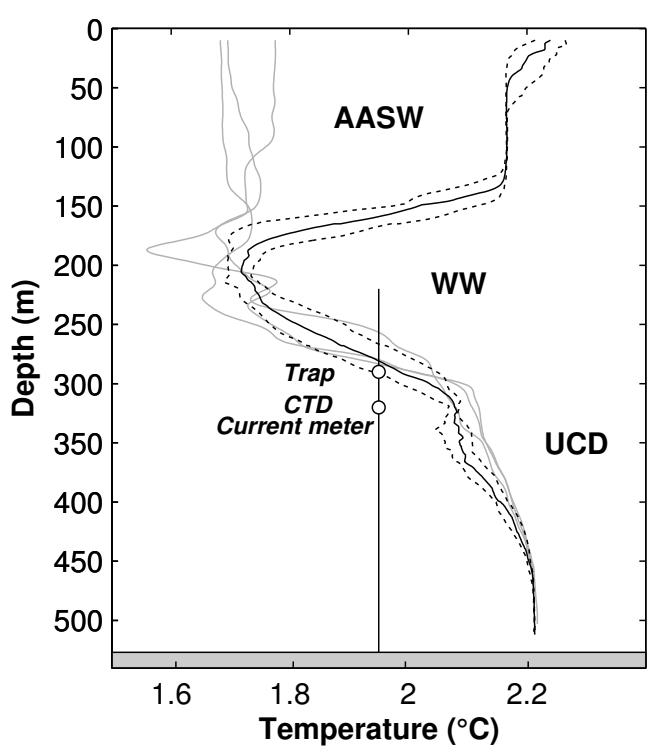

Figure 2. Schematic of the instrumented mooring line against vertical temperature profiles. The sediment trap and the current meter/CTD sensor location on the mooring line are shown by white circles. Temperature profiles performed during the sediment trap deployment (20 October 2011) are represented by grey curves. The solid black curve is the median temperature profile from 12 casts realized on the 16 November 2011. Dashed black lines are the first and third quartiles from these casts. The grey rectangle represents the Kerguelen Plateau seafloor. The different water masses are Antarctic Surface Water (AASW), Winter Water (WW) and Upper Circumpolar Deep Water (UCDW).

tistically significant (Schulz and Mudelsee, 2002), enabling the identification of periods of major variability in time series. In order to identify the water masses surrounding the trap, temperature and salinity recorded by the mooring CTD were placed in context to previous CTD casts conducted at station A3 during KEOPS1 (39 profiles, 23 January 200513 February 2005) and KEOPS2 (12 profiles, from 15 to 17 November).

\subsection{Sediment trap material analyses}

Upon recovery of the sediment trap the $\mathrm{pH}$ of the supernatant was measured in every cup and $1 \mathrm{~mL}$ of $37 \%$ formalin buffered with sodium tetraborate $(\mathrm{pH}=8)$ was added. After allowing the particulate material to settle to the base of the sample cup ( $\sim 24 \mathrm{~h}$ ), $60 \mathrm{~mL}$ of supernatant was removed with a syringe and stored separately. The samples were transported in the dark at $4{ }^{\circ} \mathrm{C}$ (JGOFS Sediment Trap Methods, 1994) and stored under identical conditions upon arrival at the laboratory until further analysis. Nitrate, nitrite, ammonium and phosphate in the supernatant were analysed colorimetrically (Aminot and Kerouel, 2007) to check for possible leaching of dissolved inorganic nitrogen and phosphorus from the particulate phase.
Samples were first transferred to a Petri dish and examined under stereomicroscope (Leica MZ8, $\times 10$ to $\times 50 \mathrm{mag}-$ nification) to determine and isolate swimmers (i.e. organisms that actively entered the cup). All swimmers were carefully sorted, cleaned (rinsed with preservative solution), enumerated and removed from the cups for further taxonomic identification. The classification of organisms as swimmers remains subjective, and there is no standardized protocol. We classified zooplankton organisms as swimmers if organic material and preserved structures could be observed. Empty shells, exuvia (exoskeleton remains) and organic debris were considered part of the passive flux. Sample preservation prevented the identification of smaller swimmers (mainly copepods), but, where possible, zooplankton were identified following Boltovskoy (1999).

Following the removal of swimmers, samples were quantitatively split into eight aliquots using a Jencons peristaltic splitter. A splitting precision of $2.9 \%$ (coefficient of variation) was determined by weighing the particulate material obtained from each of four $1 / 8$ th aliquots (see below). Aliquots for chemical analyses were centrifuged $(5 \mathrm{~min}$ at $3000 \mathrm{rpm}$ ) with the supernatant being withdrawn after this step and replaced by Milli-Q-grade water to remove salts. Milli-Q rinses were compared with ammonium formate. Organic carbon content was not statistically different even though nitrogen concentrations were significantly higher; as a consequence, Milli-Q rinses were routinely performed. The rinsing step was repeated three times. The remaining pellet was freeze-dried (SGD-SERAIL, $0.05-0.1 \mathrm{mbar},-30$ to $30^{\circ} \mathrm{C}, 48 \mathrm{~h}$ run) and weighed three times (Sartorius MC $210 \mathrm{P}$ balance, precision $\times 10^{-4} \mathrm{~g}$ ) to calculate the total mass. The particulate material was ground to a fine powder and used for measurements of particulate constituents.

For particulate organic carbon (POC) and particulate organic nitrogen (PON) analyses, 3 to $5 \mathrm{mg}$ of the freeze-dried powder was weighed directly into pre-combusted $\left(450^{\circ} \mathrm{C}\right.$, $24 \mathrm{~h})$ silver cups. Samples were decarbonated by adding $20 \mu \mathrm{L}$ of $2 \mathrm{M}$ analytical-grade hydrochloric acid (SigmaAldrich). Acidification was repeated until no bubbles could be seen, ensuring all particulate carbonate was dissolved (Salter et al., 2010). Samples were dried overnight at $50^{\circ} \mathrm{C}$. POC and PON were measured with a CHN analyser (Perkin Elmer 2400 Series II CHNS/O elemental analyser) calibrated with glycine. Samples were analysed in triplicate with an analytical precision of less than $0.7 \%$. Due to the small amount of particulate material in sample cups \#5 and \#12, replicate analyses were not possible. Uncertainty propagation for POC and PON flux was calculated as the quadratic sum of errors on mass flux and POC/PON content in each sample. The annual flux ( \pm standard deviation) was calculated as the sum of the time-integrated flux. 

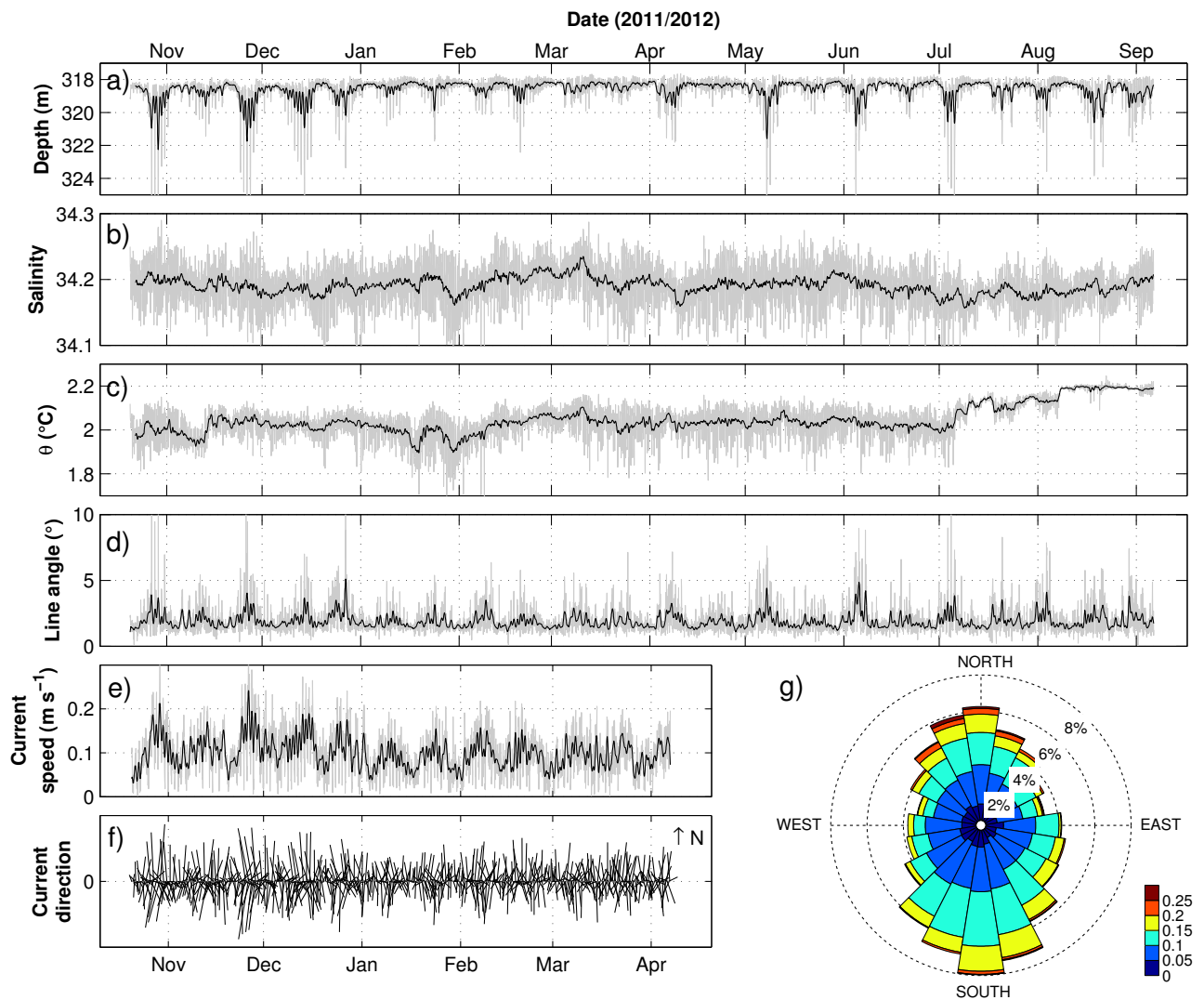

Figure 3. Hydrological properties recorded by the instrument mooring at station A3. (a) Depth of the CTD sensor, (b) salinity, (c) potential temperature, (d) line angle, and (e) current speed. In (a)-(e), grey lines are raw data, and black lines are low-pass-filtered data with a Gaussian filter ( $40 \mathrm{~h}$ window as suggested by the spectral analysis). (f) Direction and speed of currents represented by vectors (undersampled with a $5 \mathrm{~h}$ interval) and (g) wind rose plot of current direction and intensities (dotted circles are directions relatives frequencies and colours refer to current speed $\left.\left(\mathrm{m} \mathrm{s}^{-1}\right)\right)$.

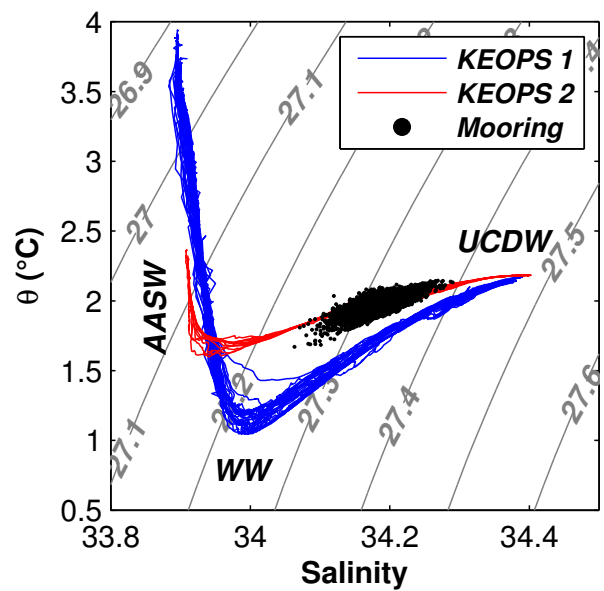

Figure 4. Potential temperature-salinity diagram at station A3. Data are from the moored CTD (black dots), KEOPS1 (blue line) and KEOPS2 (red line). Grey lines are potential density anomaly. The different water masses are Antarctic Surface Water (AASW), Winter Water (WW) and Upper Circumpolar Deep Water (UCDW).

\section{Results}

\subsection{Physical conditions around trap}

The sediment trap was deployed in the upper layers of Upper Circumpolar Deep Water (UCDW), beneath seasonally mixed Winter Water (WW; Fig. 2). The depth of the CTD sensor varied between 318 and $322 \mathrm{~m}$ ( 1 and $99 \%$ quantiles), with rare deepening to $328 \mathrm{~m}$ (Fig. 3a). Variations in tilt angle of the sediment trap were also low, mostly between 1 and $5^{\circ}$, and occasionally reaching $13^{\circ}$ (Fig. 3d). Current speed amplitude varied between 4 and $23 \mathrm{~cm} \mathrm{~s}^{-1}$ ( 1 and $99 \%$ quantiles), with a maximum value of $33 \mathrm{~cm} \mathrm{~s}^{-1}$ and a mean value of $9 \mathrm{~cm} \mathrm{~s}^{-1}$ (Fig. 3e). Horizontal flow vectors were divided between northward and southward components with strongest current speeds observed to flow northward (Fig. 3f and $\mathrm{g}$ ).

The range in potential temperature and salinity was 1.85 $2.23^{\circ} \mathrm{C}$ and $34.12-34.26$ (1-99\% quantiles; Fig. $3 \mathrm{~b}$ and c). From July to September 2012 , a mean increase of $0.2^{\circ} \mathrm{C}$ in potential temperature was associated with a strong diminution of high-frequency noise, suggesting a drift of the 

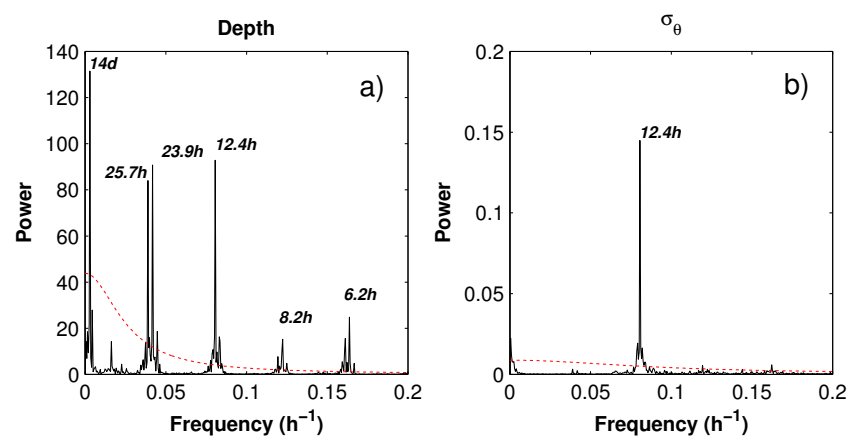

Figure 5. Power spectrum of the spectral analysis of (a) depth time series and (b) potential density anomaly time series. Pure red noise (null hypothesis) is represented by red dashed lines for each variable. The period corresponding to a significant power peak (power peak higher than the red noise) is written.

temperature sensor. Consequently these temperature data were rejected from the time series analysis. The potential temperature-salinity diagram is compared to KEOPS1 and KEOPS2 CTD downcast at station A3 (Fig. 4). The CTD sensor recorded the signature of the UCDW, and no intrusion of overlying WW could be detected.

The power spectrum of vertical sediment trap displacements identified six significant peaks corresponding to frequencies of 6.2, 8.2, 23.9 and $25.7 \mathrm{~h}$ and 14 days (Fig 5a). Concomitant peaks of depth, angle and current speed were also observed with a period of 14 days. However, spectral analysis of the potential density anomaly $\sigma_{\theta}$ revealed only one significant major power peak corresponding to a frequency of $12.4 \mathrm{~h}$ (Fig. 5b). Isopycnal displacements were driven by the unique tidal component (M2, $12.4 \mathrm{~h}$ period) and trap displacements resulted from a complex combination of multiple tidal components. The power spectrum analysis suggested that a $40 \mathrm{~h}$ window was relevant to filter out most of the short-term variability (black line in Fig. 3a-e).

A pseudo-Lagrangian trajectory was calculated by cumulating the instantaneous current vectors (Fig. 6). Over short timescales (hours to day) the trajectory displays numerous tidal ellipses. The flow direction is mainly to the southeast in October 2011 to December 2011 and northeast from December 2011 to April 2012. For the entire current meter record (6 months) the overall displacement followed a $120 \mathrm{~km}$ northeasterly, anticlockwise trajectory with an effective eastward current speed of approximately $1 \mathrm{~cm} \mathrm{~s}^{-1}$.

\subsection{Seasonality of surface chlorophyll $a$ concentration above trap location}

The seasonal variations of surface chlorophyll $a$ concentration for the sediment trap deployment period differed significantly from the long-term climatology (Fig. 7a). The bloom started at the beginning of November 2011, 10 days after the start of the sediment trap deployment. Maximum sur-

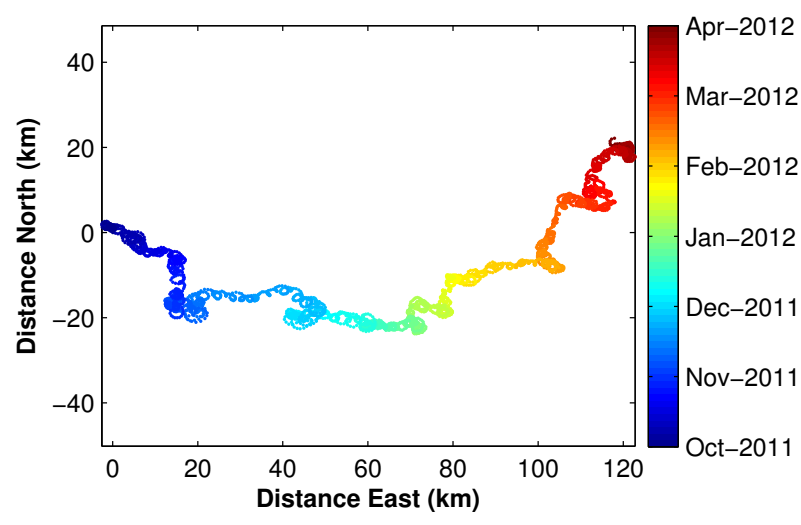

Figure 6. Progressive vector diagram (integration of the current vectors all along the current meter record) calculated from current meter data at $319 \mathrm{~m}$. The colour scale refers to date.

face chlorophyll $a$ values of $2.5 \mu \mathrm{g} \mathrm{L}-1$ occurred on the first week of November and subsequently declined rapidly to $0.2 \mu \mathrm{g} \mathrm{L}-1$ in late December 2011. A second increase in surface chlorophyll $a$ up to $1 \mu \mathrm{g} \mathrm{L}^{-1}$ occurred in January 2012, and values decreased to winter levels of $0.2 \mu \mathrm{g} \mathrm{L}^{-1}$ in February 2012. A short-term increase of $0.8 \mu \mathrm{g} \mathrm{L}^{-1}$ occurred in mid-April 2012.

\subsection{Swimmer abundances}

No swimmers were found in cups \#3 and \#5 (Table 2). Total swimmer numbers were highest in winter (1544 individuals in cup \#12). When normalized to cup opening time, swimmer intrusion rates were highest between mid-December 2011 and mid-February 2012 (from 26 to 55 individuals per day) and lower than 20 individuals per day for the remainder of the year. Swimmers were numerically dominated by copepods throughout the year, but elevated amphipod and pteropod abundances were observed at the end of January and February 2012 (Table 2). There was no significant correlation between mass flux, POC and PON fluxes and total swimmer number or intrusion rate (Spearman's correlation test, $p>0.01$ ). Copepods were essentially small cyclopoid species. Amphipods were predominantly represented by the hyperidean Cyllopus magellanicus and Themisto gaudichaudii. Pteropods were represented by Clio pyramidata, Limacina helicina forma antarctica and Limacina retroversa subsp. australis. Euphausiids were only represented by the genus Thysanoessa. One Salpa thompsoni salp (aggregate form) was found in the last winter cup \#12.

\subsection{Seasonal particulate organic carbon and nitrogen fluxes}

Particulate organic carbon flux ranged from 0.15 to $0.55 \mathrm{mmol} \mathrm{m}^{-2} \mathrm{~d}^{-1}$ during the productive period except during two short export events of $1.6 \pm 0.04$ and $1.5 \pm 0.04 \mathrm{mmol} \mathrm{m}^{-2} \mathrm{~d}^{-1}$ sampled in cups \#4 (2 to $12 \mathrm{De}$ - 

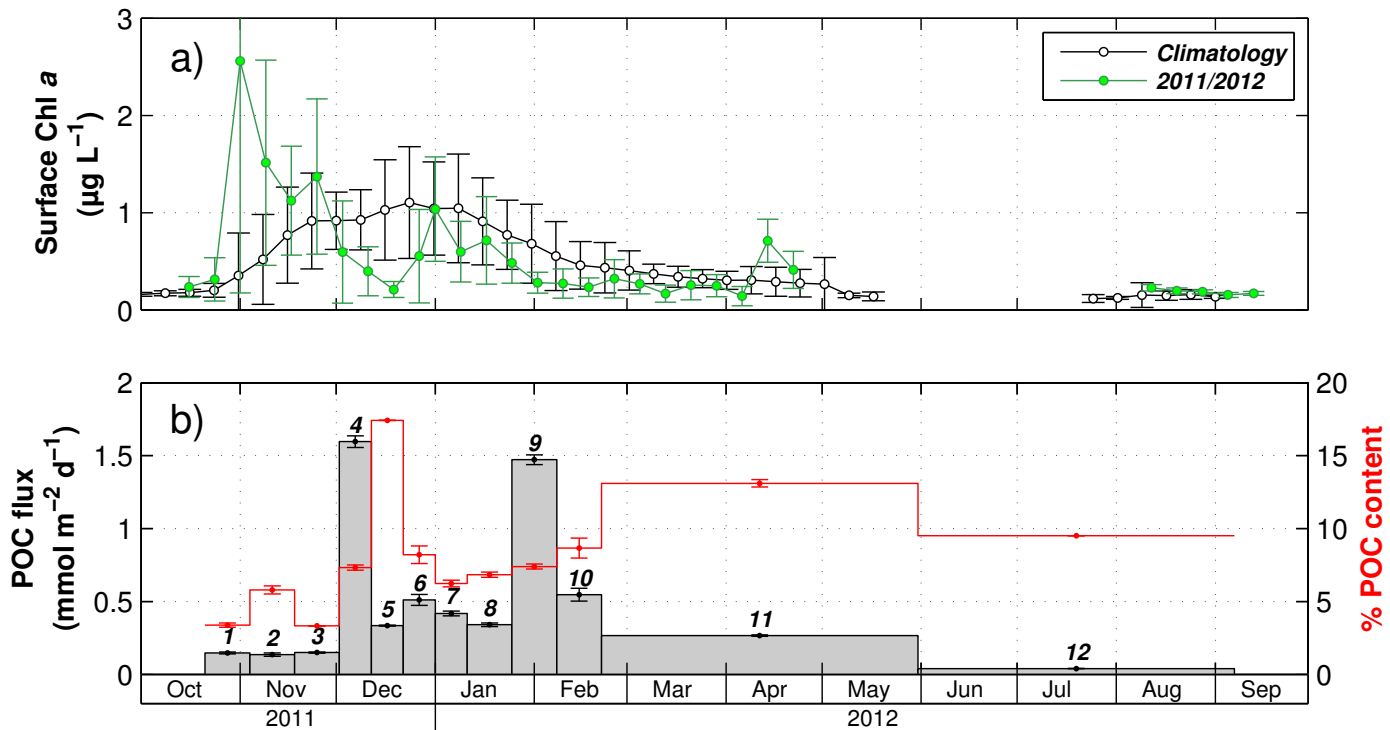

Figure 7. Seasonal variations of surface chlorophyll $a$ and particulate organic carbon (POC) export. (a) Seasonal surface chlorophyll concentration and 16-year climatology (GlobColour) averaged in a $100 \mathrm{~km}$ radius around station A3. The black line represents the climatology calculated for the period 1997/2013, whilst the green line corresponds to the sediment trap deployment period (2011/2012). (b) POC flux (grey bars) and mass percentage of POC (red dotted line). Error bars are standard deviations from triplicates, and bold italic numbers refer to cup number.

cember 2011) and \#9 (25 January to 8 February 2012), respectively (Fig. 7b). The two flux events occurred with an approximate time lag of 1 month compared to peaks in surface chlorophyll $a$ values. A modest value of $0.27 \pm 0.01 \mathrm{mmol} \mathrm{m}^{-2} \mathrm{~d}^{-1}$ was observed in autumn (cup \#11, 22 February to 30 May 2012). The lowest POC flux was measured during winter $\left(0.04 \mathrm{mmol} \mathrm{m}^{-2} \mathrm{~d}^{-1}\right.$, cup \#12, 31 May to 7 October). Assuming that POC export was negligible from mid-September to mid-October, the annually integrated POC flux was $98.2 \pm 4.4 \mathrm{mmol} \mathrm{m}^{-2} \mathrm{yr}^{-1}$ (Table 1). The two short ( $<14$ days) export events accounted for $16.2 \pm 0.5 \%$ (cup \#4) and $21.0 \pm 0.6 \%$ (cup \#9) of the annual carbon export out of the mixed layer (Table 1). Mass percentage of organic carbon ranged from 3.3 to $17.4 \%$ (Fig. 7b). Values were slightly higher in autumn and winter (respectively $13.1 \pm 0.2$ and $11 \pm 2.1 \%$ in cups \#11 and \#12) than in the summer, with the exception of cup \#5, where the highest value of $17.4 \%$ was observed. PON fluxes followed the same seasonal patterns as POC. This resulted in a relatively stable POC: $P O N$ ratio that varied between 6.1 and 7.4, except in autumn cup \#11, where it exceeded 8.1 (Table 1).

\section{Discussion}

\subsection{Physical conditions of trap deployment}

Moored sediment traps can be subject to hydrodynamic biases that affect the accuracy of particle collection (Bues- seler et al., 2007a). The aspect ratio, tilt and horizontal flow regimes are important considerations when assessing sediment trap performance. Specifically, the line angle and aspect ratio of cylindrical traps can result in oversampling (Hawley, 1988). Horizontal current velocities of $12 \mathrm{~cm} \mathrm{~s}^{-1}$ are often invoked as a critical threshold over which particles are no longer quantitatively sampled (Baker et al., 1988). During the sediment trap deployment period we observed generally low current speeds (mean $<10 \mathrm{~cm} \mathrm{~s}^{-1}$ ), with $75 \%$ of the recorded data lower than $12 \mathrm{~cm} \mathrm{~s}^{-1}$. Despite the high aspect ratio of the PPS3 trap (4.75), and the small mooring line angle deviations, it is likely that episodic increases in current velocities $\left(>12 \mathrm{~cm} \mathrm{~s}^{-1}\right)$ impacted collection efficiency. When integrated over the entire current meter record (October 2011 to April 2012), the resulting flow is consistent with the annual northeastward, low-velocity $\left(\sim 1 \mathrm{~cm} \mathrm{~s}^{-1}\right)$ geostrophic flow previously reported over the central part of the Kerguelen Plateau (Park et al., 2008b).

The depth of the winter mixed layer (WML) on the Kerguelen Plateau is usually shallower than $250 \mathrm{~m}$ (Park et al., 1998; Metzl et al., 2006). The sediment trap deployment depth of $\sim 300 \mathrm{~m}$ was selected to sample particle flux exiting the WML. The moored CTD sensor did not record any evidence of a winter water incursion during the deployment period, confirming that the WML did not reach the trap depth. The small depth variations observed during the deployment period resulted from vertical displacement of the trap. Variations in $\sigma_{\theta}$ may have resulted from both vertical displacement of the CTD sensor and possible isopycnal displacements due to strong internal waves that can occur with an 
Table 1. Dynamics of carbon and nitrogen export fluxes at station A3 collected by the sediment trap at $289 \mathrm{~m}$.

\begin{tabular}{lccccccc}
\hline & \multicolumn{5}{c}{ Fluxes $\left(\mathrm{mmol} \mathrm{m}^{-2} \mathrm{~d}^{-1}\right)$} & \multicolumn{2}{c}{ Contribution to annual export (\%) } \\
\hline Cup & Start & Stop & POC & PON & POC : PON & POC & PON \\
\hline 1 & $21 / 10 / 2011$ & $04 / 11 / 2011$ & $0.15 \pm 0.01$ & $0.02 \pm 0.00$ & $6.80 \pm 0.56$ & $2.11 \pm 0.06$ & $2.30 \pm 0.01$ \\
2 & $04 / 11 / 2011$ & $18 / 11 / 2011$ & $0.14 \pm 0.01$ & $0.02 \pm 0.00$ & $6.09 \pm 0.67$ & $1.94 \pm 0.16$ & $2.27 \pm 0.15$ \\
3 & $18 / 11 / 2011$ & $02 / 12 / 2011$ & $0.15 \pm 0.01$ & $0.02 \pm 0.00$ & $7.33 \pm 0.31$ & $2.12 \pm 0.06$ & $1.99 \pm 0.06$ \\
4 & $02 / 12 / 2011$ & $12 / 12 / 2011$ & $1.60 \pm 0.04$ & $0.23 \pm 0.01$ & $6.95 \pm 0.29$ & $16.18 \pm 0.45$ & $16.48 \pm 0.07$ \\
5 & $12 / 12 / 2011$ & $22 / 12 / 2011$ & $0.34 \pm 0.00$ & $0.05 \pm 0.00$ & $6.87 \pm 0.08$ & $3.41 \pm 0.03$ & $3.64 \pm 0.03$ \\
6 & $22 / 12 / 2011$ & $01 / 01 / 2012$ & $0.51 \pm 0.04$ & $0.08 \pm 0.01$ & $6.70 \pm 0.78$ & $4.82 \pm 0.76$ & $5.50 \pm 0.39$ \\
7 & $01 / 01 / 2012$ & $11 / 01 / 2012$ & $0.42 \pm 0.02$ & $0.06 \pm 0.00$ & $6.73 \pm 0.46$ & $4.23 \pm 0.14$ & $4.65 \pm 0.42$ \\
8 & $11 / 01 / 2012$ & $25 / 01 / 2012$ & $0.34 \pm 0.01$ & $0.05 \pm 0.00$ & $6.94 \pm 0.38$ & $4.83 \pm 0.18$ & $4.84 \pm 0.11$ \\
9 & $25 / 01 / 2012$ & $08 / 02 / 2012$ & $1.47 \pm 0.03$ & $0.20 \pm 0.01$ & $7.38 \pm 0.26$ & $20.98 \pm 0.57$ & $21.07 \pm 0.05$ \\
10 & $08 / 02 / 2012$ & $22 / 02 / 2012$ & $0.55 \pm 0.04$ & $0.08 \pm 0.00$ & $6.97 \pm 0.88$ & $7.83 \pm 0.64$ & $8.36 \pm 0.57$ \\
11 & $22 / 02 / 2012$ & $31 / 05 / 2012$ & $0.27 \pm 0.01$ & $0.03 \pm 0.00$ & $8.09 \pm 0.22$ & $26.84 \pm 0.47$ & $24.12 \pm 0.20$ \\
12 & $31 / 05 / 2012$ & $07 / 09 / 2012$ & $0.04 \pm 0.00$ & $0.01 \pm 0.00$ & $6.06 \pm 0.17$ & $4.71 \pm 0.90$ & $4.78 \pm 0.09$ \\
\hline \multicolumn{2}{l}{ Annual export (mmol m $\left.{ }^{-2} \mathrm{yr}^{-1}\right)$} & $98.24 \pm 4.35$ & $13.59 \pm 0.30$ & & & \\
\hline
\end{tabular}

amplitude of $>50 \mathrm{~m}$ at this depth (Park et al., 2008a). Our measurements demonstrate that isopycnal displacements are consistent with the M2 (moon 2, $12.4 \mathrm{~h}$ period) tidal forcing described in physical modelling studies (Maraldi et al., 2009, 2011). Spectral analysis indicates that high-frequency tidal currents are the major circulation components. Timeintegrated currents suggest that advection is weak and occurs over a longer timescale (months). Assuming the current flow measured at the sediment trap deployment depth is representative of the prevailing current under the WML, more than three months are required for particles to leave the plateau from station $\mathrm{A} 3$, a timescale larger than the bloom duration itself. Therefore we consider that the particles collected in the sediment trap at station A3 were produced in the surface waters located above the plateau during bloom conditions.

\subsection{Swimmers and particle solubilization}

Aside from the hydrodynamic effects discussed above, other potential biases characterizing sediment trap deployments, particularly those in shallow waters, are the presence of swimmers and particle solubilization. Swimmers can artificially increase POC fluxes by entering the cups and releasing particulate organic matter or decrease the flux by feeding in the trap funnel (Buesseler et al., 2007a). Some studies have focused specifically on swimmer communities collected in shallow sediment traps (Matsuno et al., 2014, and references therein), although trap collection of swimmers is probably selective and therefore not quantitative. Total swimmer intrusion rate was highest in cups \#6 to \#9 (December 2011 to February 2012) generally through the representation of copepods and amphipods (Table 2). The maximum swimmer intrusion rate in mid-summer as well as the copepod dominance is consistent with the 4-fold increase in mesozooplankton abundance observed from winter to summer (Carlotti et al., 2015). Swimmer abundance was not correlated with mass flux, POC or PON fluxes, suggesting that their presence did not systematically affect particulate fluxes inside the cups. Nevertheless such correlations cannot rule out the possibility of swimmers feeding in the trap funnel modifying particle flux collection.

Particle solubilization in preservative solutions may also lead to an underestimation of total flux measured in sediment traps. Previous analyses from traps poisoned with mercuric chloride suggest that $\sim 30 \%$ of total organic carbon flux can be found in the dissolved phase and much higher values of 50 and $90 \%$ may be observed for nitrogen and phosphorous, respectively (Antia, 2005; O'Neill et al., 2005). Unfortunately the use of a formaldehyde-based preservative in our trap samples precludes any direct estimate of excess of dissolved organic carbon in the sample cup supernatant. Furthermore, corrections for particle leaching have been considered problematic in the presence of swimmers since a fraction of the leaching may originate from the swimmers themselves (Antia, 2005), potentially leading to overcorrection. Particle solubilization may have occurred in our samples, as evidenced by excess $\mathrm{PO}_{4}^{3-}$ in the supernatant. However the largest values were measured in sample cups where total swimmers were abundant (cups \#8 to \#12; data not shown). Consequently, it was not possible to discriminate solubilization of $\mathrm{P}$ from swimmers and passively settling particles, and it therefore remains difficult to quantify the effect of particle leaching. However, leaching of POC should be less problematic in formalin-preserved samples because aldehydes fix organic matter, in addition to poisoning microbial activity.

\subsection{Seasonal dynamics of POC export}

The sediment trap record obtained from station A3 provides the first direct estimate of POC export covering an entire sea- 
Table 2. Number of swimmer individuals found in each cup and swimmer intrusion rate (number per day, bold numbers) for each taxa and for the total swimmers.

\begin{tabular}{|c|c|c|c|c|c|c|c|c|c|c|c|}
\hline Cup & Copepod & Pteropod & Euphausid & Ostracod & Amphipod & Cnidarian & Polychaete & Ctenophore & Siphonophore & Salp & Total \\
\hline \multirow[t]{2}{*}{1} & 166 & 13 & 1 & 2 & 1 & 0 & 0 & 0 & 0 & 0 & 183 \\
\hline & 12 & 1 & $<1$ & $<1$ & $<1$ & 0 & $\mathbf{0}$ & $\mathbf{0}$ & $\mathbf{0}$ & 0 & 13 \\
\hline \multirow[t]{2}{*}{2} & 55 & 0 & 0 & 0 & 0 & 0 & 0 & 0 & 0 & 0 & 55 \\
\hline & 4 & $\mathbf{0}$ & 0 & $\mathbf{0}$ & $\mathbf{0}$ & $\mathbf{0}$ & $\mathbf{0}$ & $\mathbf{0}$ & $\mathbf{0}$ & 0 & 4 \\
\hline \multirow[t]{2}{*}{3} & 0 & 0 & 0 & 0 & 0 & 0 & 0 & 0 & 0 & 0 & 0 \\
\hline & $\mathbf{0}$ & $\mathbf{0}$ & 0 & $\mathbf{0}$ & 0 & 0 & 0 & 0 & 0 & 0 & 0 \\
\hline \multirow[t]{2}{*}{4} & 113 & 0 & 0 & 0 & 0 & 0 & 0 & 0 & 0 & 0 & 113 \\
\hline & 11 & $\mathbf{0}$ & $\mathbf{0}$ & $\mathbf{0}$ & $\mathbf{0}$ & $\mathbf{0}$ & $\mathbf{0}$ & $\mathbf{0}$ & $\mathbf{0}$ & $\mathbf{0}$ & 11 \\
\hline \multirow[t]{2}{*}{5} & 0 & 0 & 0 & 0 & 0 & 0 & 0 & 0 & 0 & 0 & 0 \\
\hline & $\mathbf{0}$ & $\mathbf{0}$ & $\mathbf{0}$ & $\mathbf{0}$ & $\mathbf{0}$ & $\mathbf{0}$ & $\mathbf{0}$ & 0 & 0 & 0 & 0 \\
\hline \multirow[t]{2}{*}{6} & 540 & 0 & 1 & 0 & 2 & 5 & 1 & 4 & 1 & 0 & 554 \\
\hline & 54 & 0 & $<1$ & 0 & $<1$ & $<1$ & 0 & 0 & o & 0 & 55 \\
\hline \multirow[t]{2}{*}{7} & 583 & 0 & 0 & 0 & 0 & 2 & 2 & 3 & 0 & 0 & 590 \\
\hline & 58 & 0 & 0 & 0 & 0 & $<1$ & $<1$ & $<1$ & 0 & 0 & 58 \\
\hline \multirow[t]{2}{*}{8} & 686 & 33 & 2 & 2 & 8 & 5 & 1 & 4 & 0 & 0 & 741 \\
\hline & 49 & 2 & $<1$ & $<1$ & 1 & $<1$ & $<1$ & $<1$ & 0 & 0 & 52 \\
\hline \multirow[t]{2}{*}{9} & 392 & 14 & 4 & 3 & 121 & 4 & 2 & 0 & 0 & 0 & 540 \\
\hline & 28 & 1 & $<1$ & $<1$ & 9 & $<1$ & $<1$ & 0 & 0 & 0 & 38 \\
\hline \multirow[t]{2}{*}{10} & 264 & 69 & 1 & 2 & 18 & 11 & 0 & 2 & 0 & 0 & 367 \\
\hline & 19 & 5 & $<1$ & $<1$ & 1 & 1 & 0 & $<1$ & 0 & 0 & 26 \\
\hline \multirow[t]{2}{*}{11} & 54 & 0 & 0 & 0 & 29 & 4 & 1 & 0 & 0 & 0 & 88 \\
\hline & 1 & $\mathbf{0}$ & 0 & 0 & $<1$ & $<1$ & $<1$ & 0 & 0 & 0 & 1 \\
\hline \multirow[t]{2}{*}{12} & 1481 & 44 & 5 & 7 & 2 & 3 & 2 & 0 & 0 & 1 & 1544 \\
\hline & 15 & $<1$ & $<1$ & $<1$ & $<1$ & $<1$ & $<1$ & 0 & 0 & $<1$ & 15 \\
\hline
\end{tabular}

son over the naturally fertilized Kerguelen Plateau. We observed a temporal lag of 1 month between the two surface chlorophyll $a$ peaks and the two export events. Based on a compilation of annual sediment trap deployments, Lutz et al. (2007) reported that export quickly follows primary production at low latitudes, whereas a time lag up to 2 months could occur at higher latitudes. A 1-2-month lag was observed between production and export in the pacific sector of the Southern Ocean (Buesseler et al., 2001), as well as along $170^{\circ} \mathrm{W}$ (Honjo et al., 2000) and in the Australian sector of the Subantarctic Zone (Rigual-Hernández et al., 2015). The temporal lag between surface production and measured export in deep traps can originate from ecological processes in the upper ocean (e.g. carbon retention in the mixed layer) as well as slow sinking velocities (Armstrong et al., 2009), and one cannot differentiate the two processes from a single deep trap signal. A global-scale modelling study suggests that the strongest temporal decoupling between production and export (more than 1 month) occurs in areas characterized by a strong seasonal variability in primary production (Henson et al., 2014). The study attributes this decoupling to differences in phenology of phytoplankton and zooplankton and evokes zooplankton ejection products as major contributors to fastsinking particles sedimenting post-bloom.

On the Kerguelen Plateau there is evidence that a significant fraction of phytoplankton biomass comprising the two chlorophyll peaks is remineralized by a highly active heterotrophic microbial community (Obernosterer et al., 2008;
Christaki et al., 2014). Another fraction is likely channelled toward higher trophic levels through the intense grazing pressure that supports the observed increase in zooplankton biomass (Carlotti et al., 2008, 2015). Therefore an important fraction of phytoplankton biomass increases observed by satellite may not contribute to export fluxes. Notably, the POC: $P O N$ ratio measured in our trap material is close to values reported for marine diatoms $(7.3 \pm 1.2$; Sarthou et al., 2005) compared to the $\mathrm{C}: \mathrm{N}$ ratio of zooplankton faecal pellets, which is typically higher (7.3 to $>15$, Gerber and Gerber, 1979; Checkley and Entzeroth, 1985; Morales, 1987). Simple mass balance would therefore suggest a significant contribution of phytoplanktonic cells to the POC export, which is indeed corroborated by detailed microscopic analysis (Rembauville et al., 2015).

Although we observed increasing contributions of faecal pellet carbon post-bloom (Rembauville et al., 2015), in line with the model output of Henson et al. (2014), differences in phytoplankton and zooplankton phenology do not fully explain the seasonality of export on the Kerguelen Plateau. Considering the shallow trap depth $(289 \mathrm{~m})$ and typical sinking speed of $100 \mathrm{~m} \mathrm{~d}^{-1}$ for phyto-aggregates (Allredge and Gotschalk, 1988; Peterson et al., 2005; Trull et al., 2008a), aggregate-driven export following bloom demise would suggest a short lag of a few days between production and export peaks. The temporal lag of 1 month measured in the present study suggests either slow sinking rates $\left(<5 \mathrm{~m} \mathrm{~d}^{-1}\right)$ characteristic of single phytoplanktonic cells or faster-sinking par- 
ticles that originate from subsurface production peaks undetected by satellite. It is generally accepted that satellite detection depth is $20-50 \mathrm{~m}$ (Gordon and McCluney, 1975), and can be less than $20 \mathrm{~m}$ when surface chlorophyll $a$ exceeds $0.2 \mu \mathrm{g} \mathrm{L}-1$ (Smith, 1981), which prevents the detection of deep phytoplanktonic biomass structures (Villareal et al., 2011). Although subsurface chlorophyll maxima located around $100 \mathrm{~m}$ have been observed over the Kerguelen Plateau at the end of the productive period, they have been interpreted to result from the accumulation of surface production at the base of the mixed layer rather than subsurface productivity features (Uitz et al., 2009). In support of this, detailed taxonomic analysis of the exported material highlights diatom resting spores as major contributors to the two export fluxes rather than a composite surface community accumulated at the base of the mixed layer. The hypothesis of a mass production of nutrient-limited resting spores post-bloom with high settling rates explains the temporal patterns of export we observed (Rembauville et al., 2015). However a better knowledge of the dynamics of factors responsible for resting spore formation by diatoms remains necessary to fully validate this hypothesis.

\subsection{Evidence for significant flux attenuation over the Kerguelen Plateau}

The Kerguelen Plateau annual POC export $\left(98.2 \pm 4.4 \mathrm{mmol} \mathrm{m}^{-2} \mathrm{yr}^{-1}\right)$ approaches the median global ocean POC export value comprising shallow and deep sediment traps $\left(83 \mathrm{mmol} \mathrm{m}^{-2} \mathrm{yr}^{-1}\right.$; Lampitt and Antia, 1997), but is also close to values observed in HNLC areas of the POOZ $\left(11-43 \mathrm{mmol} \mathrm{m}^{-2} \mathrm{yr}^{-1}\right.$ at $500 \mathrm{~m}$; Fischer et al., 2000). Moreover, the magnitude of annual POC export measured at $\sim 300 \mathrm{~m}$ on the Kerguelen Plateau is comparable to deep-ocean $(>2 \mathrm{~km})$ POC fluxes measured from the iron-fertilized Crozet $\left(60 \mathrm{mmol} \mathrm{m}^{-2} \mathrm{yr}^{-1}\right.$; Salter et al., 2012) and South Georgia blooms $\left(180 \mathrm{mmol} \mathrm{m}^{-2} \mathrm{yr}^{-1}\right.$; Manno et al., 2015).

We first compared the sediment trap export fluxes with short-term estimates at $200 \mathrm{~m}$ in spring (KEOPS2) and summer (KEOPS1). The POC flux recorded in the moored sediment trap represents only a small fraction $(3-8 \%)$ of the POC flux measured at the base of the winter mixed layer $(200 \mathrm{~m})$ by different approaches during the spring KEOPS2 cruise (Table 3). The same conclusion can be drawn when considering the comparison with different estimates made at the end of summer during KEOPS1. Moreover, the annual POC export of $\sim 0.1 \mathrm{~mol} \mathrm{~m}^{-2} \mathrm{yr}^{-1}$ at $289 \mathrm{~m}$ (Table 1) represents only $2 \%$ of the indirect estimate of POC export $\left(5.1 \mathrm{~mol} \mathrm{~m}^{-2} \mathrm{yr}^{-1}\right)$ at the base of the WML $(200 \mathrm{~m})$ on the Kerguelen Plateau based on a seasonal dissolved inorganic carbon (DIC) budget (Blain et al., 2007). The short-term estimates are derived from a diverse range of methods. The ${ }^{234} \mathrm{Th}$ proxy is based on the ${ }^{234} \mathrm{Th}$ deficit relative to the ${ }^{238} \mathrm{U}$ due to its adsorption on particles, and its subsequent con- version to carbon fluxes using measured POC: ${ }^{234} \mathrm{Th}$ ratios. (Coale and Bruland, 1985; Buesseler et al., 2006; Savoye et al., 2006). The UVP (underwater video profiler) provides high-resolution images of particles $(>52 \mu \mathrm{m})$, and the particle size distribution is then converted to carbon fluxes using an empirical relationship (Guidi et al., 2008; Picheral et al., 2010). Drifting gel traps allow for the collection, preservation and imaging of sinking particles $(>71 \mu \mathrm{m})$ that are converted to carbon fluxes using empirical volume-carbon relationship (Ebersbach and Trull, 2008; Ebersbach et al., 2011; Laurenceau-Cornec et al., 2015). Finally, drifting sediment traps are conceptually similar to moored sediment traps but avoid most of the hydrodynamic biases associated with this technique (Buesseler et al., 2007a). The diversity of the methods and differences in depth where the POC flux was estimated render quantitative comparisons challenging. Nevertheless, POC fluxes measured at $289 \mathrm{~m}$ with the moored sediment trap are considerably lower than other estimates made at $200 \mathrm{~m}$. This result indicates either extremely rapid attenuation of flux between 200 and $300 \mathrm{~m}$ or significant sampling bias by the sediment trap.

We note that low carbon export fluxes around $300 \mathrm{~m}$ have been previously reported on the Kerguelen Plateau. In spring 2011, UVP-derived estimates of POC export at $350 \mathrm{~m}$ were 0.1 to $0.3 \mathrm{mmol} \mathrm{m}^{-2} \mathrm{~d}^{-1}$ (Table 3), values close to our reported value of $0.15 \mathrm{mmol} \mathrm{m}^{-2} \mathrm{~d}^{-1}$. In summer 2005, POC export at $330 \mathrm{~m}$ from a gel trap was $0.7 \mathrm{mmol} \mathrm{m}^{-2} \mathrm{~d}^{-1}$ (Ebersbach and Trull 2008), which is also close to our value of $1.5 \mathrm{mmol} \mathrm{m}^{-2} \mathrm{~d}^{-1}$. Using the Jouandet et al. (2014) data at $200 \mathrm{~m}\left(1.9 \mathrm{mmol} \mathrm{m}^{-2} \mathrm{~d}^{-1}\right)$ and $350 \mathrm{~m}\left(0.3 \mathrm{mmol} \mathrm{m}^{-2} \mathrm{~d}^{-1}\right)$ and the Ebersbach and Trull (2008) data at $200 \mathrm{~m}\left(5.2 \mathrm{mmol} \mathrm{m}^{-2} \mathrm{~d}^{-1}\right)$ and $330 \mathrm{~m}$ $\left(0.7 \mathrm{mmol} \mathrm{m}^{-2} \mathrm{~d}^{-1}\right)$ leads to Martin power-law exponent values of 3.3 and 4 , respectively. These values are high when compared to the range of $0.4-1.7$ that was initially compiled for the global ocean (Buesseler et al., 2007b). However, there is increasing evidence in support of much higher $b$ values in the Southern Ocean that fall in the range of 0.9-3.9 (Lam and Bishop, 2007; Henson et al., 2012; Cavan et al., 2015). Our calculations are thus consistent with emerging observations of significant POC flux attenuation in the Southern Ocean.

Using the aforementioned $b$ values (3.3 and 4) and the POC flux derived from ${ }^{234} \mathrm{Th}$ deficit at $200 \mathrm{~m}$ in spring (Planchon et al., 2014), we estimate POC fluxes at $289 \mathrm{~m}$ of 0.7 to $1.1 \mathrm{mmol} \mathrm{m}^{-2} \mathrm{~d}^{-1}$. The flux measured in our sediment trap $\left(0.15 \mathrm{mmol} \mathrm{m}^{-2} \mathrm{~d}^{-1}\right)$ data represents 14 to $21 \%$ of this calculated flux. Very similar percentages (21 to $27 \%$ ) are found using the POC fluxes derived from the ${ }^{234} \mathrm{Th}$ deficit in summer (Savoye et al., 2008). Therefore we consider that the moored sediment trap collected $\sim 15-30 \%$ of the ${ }^{234} \mathrm{Th}-$ derived particle flux equivalent throughout the year. Trapderived particle fluxes can represent 0.1 to $>3$ times the ${ }^{234} \mathrm{Th}$-derived particles in shallow sediment traps (Buesseler, 1991; Buesseler et al., 1994; Coppola et al., 2002; Gustafsson et al., 2004), and this difference is largely attributed to the 
Table 3. Summary of estimates of POC fluxes at the base of, or under, the mixed layer at station A3 from the KEOPS cruises.

\begin{tabular}{|c|c|c|c|c|}
\hline Author & Method & Period & Depth (m) & $\begin{array}{c}\text { POC flux } \\
\left(\mathrm{mmol} \mathrm{m}^{-2} \mathrm{~d}^{-1}\right)\end{array}$ \\
\hline & \multicolumn{4}{|c|}{ KEOPS1 } \\
\hline \multirow{3}{*}{ Savoye et al. (2008) } & \multirow{3}{*}{${ }^{234}$ Th deficit } & \multirow[t]{3}{*}{23 Jan-12 Feb 2005} & 100 & $23 \pm 3.6$ \\
\hline & & & 150 & $25.7 \pm 3.6$ \\
\hline & & & 200 & $24.5 \pm 6.8$ \\
\hline \multirow{5}{*}{ Ebersbach and Trull (2008) } & \multirow{5}{*}{$\begin{array}{l}\text { Drifting gel trap, } \\
\text { optical measurements, and } \\
\text { both constant and power- } \\
\text { law C conversion factor }\end{array}$} & \multirow{5}{*}{$\begin{array}{l}4 \text { Feb } 2005 \\
12 \text { Feb } 2005\end{array}$} & 200 & 23.9 \\
\hline & & & 100 & 5.3 \\
\hline & & & 200 & 5.2 \\
\hline & & & 330 & 0.7 \\
\hline & & & 430 & 1 \\
\hline Jouandet et al. (2008) & Annual DIC budget & Annual & MLD base & 85 \\
\hline \multirow[t]{2}{*}{ Trull et al. (2008b) } & \multirow{2}{*}{ Drifting sediment trap } & 4 Feb 2005 & 200 & $7.3-10$ \\
\hline & & 12 Feb 2005 & 200 & $3-3.1$ \\
\hline \multirow{10}{*}{ Jouandet et al. (2011) } & \multirow{9}{*}{$\begin{array}{l}\text { In situ optical } \\
\text { measurement (UVP) and power } \\
\text { function } \mathrm{C} \text { conversion factor }\end{array}$} & \multirow[t]{3}{*}{22 Jan 2005} & 200 & 72.4 \\
\hline & & & 330 & 27.2 \\
\hline & & & 400 & 21.6 \\
\hline & & \multirow[t]{3}{*}{23 Jan 2005} & 200 & 29.8 \\
\hline & & & 330 & 26.8 \\
\hline & & & 400 & 15.9 \\
\hline & & \multirow[t]{3}{*}{12 Feb 2005} & 200 & 4.8 \\
\hline & & & 330 & 5.6 \\
\hline & & & 400 & 7.9 \\
\hline & \multicolumn{4}{|c|}{ KEOPS2 } \\
\hline \multirow{9}{*}{ Planchon et al. (2014) } & \multirow{6}{*}{$\begin{array}{l}{ }^{234} \mathrm{Th} \text { deficit, } \\
\text { steady-state model }\end{array}$} & \multirow[t]{2}{*}{20 Oct 2011} & 100 & $3.5 \pm 0.9$ \\
\hline & & & 150 & $3.9 \pm 0.9$ \\
\hline & & \multirow{4}{*}{16 Nov 2011} & 200 & $3.7 \pm 0.9$ \\
\hline & & & 100 & $4.6 \pm 1.5$ \\
\hline & & & 150 & $7.1 \pm 1.5$ \\
\hline & & & 200 & $3.1 \pm 0.6$ \\
\hline & \multirow{3}{*}{$\begin{array}{l}{ }^{234} \mathrm{Th} \text { deficit, } \\
\text { non-steady-state model }\end{array}$} & \multirow[t]{3}{*}{16 Nov 2011} & 100 & $7.3 \pm 1.8$ \\
\hline & & & 150 & $8.4 \pm 1.8$ \\
\hline & & & 200 & $3.8 \pm 0.8$ \\
\hline \multirow[t]{2}{*}{ Laurenceau-Cornec et al. (2015) } & $\begin{array}{l}\text { Drifting gel trap, optical } \\
\text { measurement of particles }\end{array}$ & \multirow[t]{2}{*}{16 Nov 2011} & 210 & 5.5 \\
\hline & Drifting sediment trap & & 210 & 2.2 \\
\hline \multirow{4}{*}{ Jouandet et al. (2014) } & \multirow{4}{*}{$\begin{array}{l}\text { In situ optical measurement } \\
\text { (UVP) and power function C } \\
\text { conversion factor }\end{array}$} & \multirow[t]{2}{*}{21 Oct 2011} & 200 & 0.2 \\
\hline & & & 350 & 0.1 \\
\hline & & \multirow[t]{2}{*}{16 Nov 2011} & 200 & 1.9 \\
\hline & & & 350 & 0.3 \\
\hline
\end{tabular}

sum of hydrodynamic biases and swimmer activities (Buesseler, 1991), although it probably also includes the effect of post-collection particle solubilization. In the Antarctic Peninsula, ${ }^{234}$ Th-derived POC export was 20 times higher than the fluxes collected by a shallow, cylindrical, moored sediment trap at $170 \mathrm{~m}$ (Buesseler et al., 2010). The present deployment context is less extreme (depth of $289 \mathrm{~m}$, mean current speed $<10 \mathrm{~cm} \mathrm{~s}^{-1}$, low tilt angle, high aspect ratio of the cylindrical PPS3 trap) but we consider that hydrodynamics (current speed higher than $12 \mathrm{~cm} \mathrm{~s}^{-1}$ during short tidaldriven events) and possible zooplankton feeding on the trap funnel are potential biases that may explain in part the low fluxes recorded by the moored sediment trap. Therefore the low fluxes observed likely result from a combined effect of collection bias (hydrodynamics and swimmers) and attenuation of the POC flux between the base of the WML and 
$300 \mathrm{~m}$. However, it is not possible with the current data set to isolate a specific explanation for low flux values.

Strong POC flux attenuation over the Kerguelen Plateau compared to the open ocean is also reported by LaurenceauCornec et al. (2015), who associated this characteristic with an HBLE scenario and invoked the role of mesozooplankton in the carbon flux attenuation. Between October and November 2011, mesozooplankton biomass in the mixed layer doubled (Carlotti et al., 2014) and summer biomass was a further 2-fold higher (Carlotti et al., 2008). These seasonal patterns are consistent with the maximum swimmer intrusion rate and swimmer diversity observed in summer (Table 2). It has previously been concluded that zooplankton biomass is more tightly coupled to phytoplankton biomass on the plateau compared to oceanic waters, leading to higher secondary production on the plateau (Carlotti et al., 2008, 2014). The findings of Cavan et al. (2015) that document the lowest export ratio (exported production/primary production) in the most productive, naturally fertilized area downstream of South Georgia provide further support linking zooplankton dynamics to HBLE environments of iron-fertilized blooms. Another important ecosystem feature associated with the HBLE environment of the Kerguelen Plateau, and likely shared by other island-fertilized blooms in the Southern Ocean, is the presence of mesopelagic fish (myctophid spawning and larvae foraging site; Koubbi et al., 1991, 2001). Mesopelagic fish can be tightly coupled to lower trophic levels (Saba and Steinberg, 2012) and can play a significant role in carbon flux attenuation (Davison et al., 2013). Although important for carbon budgets, mesopelagic fish represents a compartment often neglected due to the challenge of quantitative sampling approaches. We suggest that the HBLE scenario and large attenuation of carbon flux beneath the WML at Kerguelen may reflect the transfer of carbon biomass to higher and mobile trophic groups that fuel large mammal and bird populations rather than the classical remineralization-controlled attenuation characterizing open-ocean environments. Although technically challenging, testing this hypothesis should be a focus for future studies in this and similar regions.

\section{Conclusions}

We report the seasonal dynamics of particulate organic carbon (POC) export under the winter mixed layer $(289 \mathrm{~m})$ of the naturally iron-fertilized and productive central Kerguelen Plateau. Annual POC flux was remarkably low $\left(98 \mathrm{mmol} \mathrm{m}^{-2}\right)$ and occurred primarily during two episodic ( $<14$ days) flux events exported with a 1-month lag following two surface chlorophyll $a$ peaks. Analysis of the hydrological conditions and a comparison with different estimates of POC fluxes in spring and summer at the same station suggests that the sediment trap was subject to possible hydrodynamic and biological biases leading to under-collection of particle flux. Nevertheless, the low POC export was close to other estimates of deep (> $300 \mathrm{~m}$ ) POC export at the same station and is consistent with high attenuation coefficients reported from other methods. We invoke heterotrophic microbial activity and mesozooplankton and mesopelagic fish activity as possible explanations for efficient carbon flux attenuation and/or transfer to higher trophic levels which results in a high-biomass, low-export environment.

The biogenic silicon, diatoms assemblages and faecal pellet fluxes are reported in a companion paper that identifies the primary ecological vectors regulating the magnitude of POC export and seasonal patterns in BSi : POC export (Rembauville et al., 2015).

Acknowledgements. We thank the chief scientist, Bernard Quéguiner, and Captain Bernard Lassiette and his crew on the R/V Marion Dufresne II during the KEOPS2 mission. We thank Leanne Armand and Tom Trull for their constructive comments, as well as the three anonymous reviewers who helped us to improve the manuscript. This work was supported by the French Research programme of INSU-CNRS LEFE-CYBER (Les enveloppes fluides et l'environnement - Cycles biogéochimiques, environnement et ressources), the French ANR (Agence Nationale de la Recherche, SIMI-6 programme, ANR-10-BLAN0614), the French CNES (Centre National d'Etudes Spatiales) and the French Polar Institute IPEV (Institut Polaire Paul-Emile Victor).

Edited by: T. Trull

\section{References}

Allredge, A. L. and Gotschalk, C.: In situ settling behavior of marine snow, Limnol. Oceanogr., 33, 339-351, 1988.

Aminot, A. and Kerouel, R.: Dosage automatique des nutriments dans les eaux marines: méthodes en flux continu, Ifremer, Plouzané, France, 2007.

Antia, A. N.: Solubilization of particles in sediment traps: revising the stoichiometry of mixed layer export, Biogeosciences, 2, 189204, doi:10.5194/bg-2-189-2005, 2005.

Armstrong, R. A., Peterson, M. L., Lee, C., and Wakeham, S. G.: Settling velocity spectra and the ballast ratio hypothesis, DeepSea Res. Pt. II, 56, 1470-1478, doi:10.1016/j.dsr2.2008.11.032, 2009.

Baker, E. T., Milburn, H. B., and Tennant, D. A.: Field assessment of sediment trap efficiency under varying flow conditions, J. Mar. Res., 46, 573-592, doi:10.1357/002224088785113522, 1988.

Barbeau, K., Moffett, J. W., Caron, D. A., Croot, P. L., and Erdner, D. L.: Role of protozoan grazing in relieving iron limitation of phytoplankton, Nature, 380, 61-64, doi:10.1038/380061a0, 1996.

Batten, S. D. and Gower, J. F. R.: Did the iron fertilization near Haida Gwaii in 2012 affect the pelagic lower trophic level ecosystem?, J. Plankton Res., 36, 925-932, doi:10.1093/plankt/fbu049, 2014.

Blain, S., Tréguer, P., Belviso, S., Bucciarelli, E., Denis, M., Desabre, S., Fiala, M., Martin Jézéquel, V., Le Fèvre, J., Mayzaud, P., Marty, J.-C., and Razouls, S.: A biogeochemical 
study of the island mass effect in the context of the iron hypothesis: Kerguelen Islands, Southern Ocean, Deep-Sea Res. Pt. I, 48, 163-187, doi:10.1016/S0967-0637(00)00047-9, 2001.

Blain, S., Quéguiner, B., Armand, L., Belviso, S., Bombled, B., Bopp, L., Bowie, A., Brunet, C., Brussaard, C., Carlotti, F., Christaki, U., Corbière, A., Durand, I., Ebersbach, F., Fuda, J.L., Garcia, N., Gerringa, L., Griffiths, B., Guigue, C., Guillerm, C., Jacquet, S., Jeandel, C., Laan, P., Lefèvre, D., Lo Monaco, C., Malits, A., Mosseri, J., Obernosterer, I., Park, Y.-H., Picheral, M., Pondaven, P., Remenyi, T., Sandroni, V., Sarthou, G., Savoye, N., Scouarnec, L., Souhaut, M., Thuiller, D., Timmermans, K., Trull, T., Uitz, J., van Beek, P., Veldhuis, M., Vincent, D., Viollier, E., Vong, L., and Wagener, T.: Effect of natural iron fertilization on carbon sequestration in the Southern Ocean, Nature, 446, 10701074, doi:10.1038/nature05700, 2007.

Boltovskoy, D.: South Atlantic zooplankton, Backhuys, 1999.

Bopp, L., Kohfeld, K. E., Le Quéré, C., and Aumont, O.: Dust impact on marine biota and atmospheric $\mathrm{CO}_{2}$ during glacial periods, Paleoceanography, 18, 1046, doi:10.1029/2002PA000810, 2003

Boyd, P. W. and Trull, T. W.: Understanding the export of biogenic particles in oceanic waters: Is there consensus?, Prog. Oceanogr., 72, 276-312, doi:10.1016/j.pocean.2006.10.007, 2007.

Boyd, P. W., Law, C. S., Hutchins, D. A., Abraham, E. R., Croot, P. L., Ellwood, M., Frew, R. D., Hadfield, M., Hall, J., Handy, S., Hare, C., Higgins, J., Hill, P., Hunter, K. A., LeBlanc, K., Maldonado, M. T., McKay, R. M., Mioni, C., Oliver, M., Pickmere, S., Pinkerton, M., Safi, K., Sander, S., SanudoWilhelmy, S. A., Smith, M., Strzepek, R., Tovar-Sanchez, A., and Wilhelm, S. W.: FeCycle: Attempting an iron biogeochemical budget from a mesoscale SF6 tracer experiment in unperturbed low iron waters, Glob. Biogeochem. Cy., 19, GB4S20, doi:10.1029/2005GB002494, 2005.

Boyd, P. W., Jickells, T., Law, C. S., Blain, S., Boyle, E. A., Buesseler, K. O., Coale, K. H., Cullen, J. J., Baar, H. J. W. de, Follows, M., Harvey, M., Lancelot, C., Levasseur, M., Owens, N. P. J., Pollard, R., Rivkin, R. B., Sarmiento, J., Schoemann, V., Smetacek, V., Takeda, S., Tsuda, A., Turner, S., and Watson, A. J.: Mesoscale Iron Enrichment Experiments 19932005: Synthesis and Future Directions, Science, 315, 612-617, doi:10.1126/science.1131669, 2007.

Buesseler, K. O.: Do upper-ocean sediment traps provide an accurate record of particle flux?, Nature, 353, 420-423, doi:10.1038/353420a0, 1991 .

Buesseler, K. O. and Boyd, P. W.: Shedding light on processes that control particle export and flux attenuation in the twilight zone of the open ocean, Limnol. Oceanogr., 54, 1210-1232, doi:10.4319/lo.2009.54.4.1210, 2009.

Buesseler, K. O., Michaels, A. F., Siegel, D. A., and Knap, A. H.: A three dimensional time-dependent approach to calibrating sediment trap fluxes. Glob. Biogeochem. Cy., 8, 179-193, doi:10.1029/94GB00207, 1994.

Buesseler, K. O., Ball, L., Andrews, J., Cochran, J. K., Hirschberg, D. J., Bacon, M. P., Fleer, A., and Brzezinski, M.: Upper ocean export of particulate organic carbon and biogenic silica in the Southern Ocean along $170^{\circ} \mathrm{W}$, Deep-Sea Res. Pt. II, 48, 42754297, doi:10.1016/S0967-0645(01)00089-3, 2001.

Buesseler, K. O., Benitez-Nelson, C. R., Moran, S. B., Burd, A., Charette, M., Cochran, J. K., Coppola, L., Fisher, N. S., Fowler,
S. W., Gardner, W. D., Guo, L. D., Gustafsson, Ö., Lamborg, C., Masque, P., Miquel, J. C., Passow, U., Santschi, P. H., Savoye, N., Stewart, G., and Trull, T.: An assessment of particulate organic carbon to thorium-234 ratios in the ocean and their impact on the application of 234Th as a POC flux proxy, Future Applications of 234Th in Aquatic Ecosystems (FATE), Mar. Chem., 100, 213 233, doi:10.1016/j.marchem.2005.10.013, 2006.

Buesseler, K. O., Antia, A. N., Chen, M., Fowler, S. W., Gardner, W. D., Gustafsson, Ö., Harada, K., Michaels, A. F., Rutgers V. D. Loeff, M., Sarin, M., Steinberg, D. K., and Trull, T.: An assessment of the use of sediment traps for estimating upper ocean particle fluxes, J. Mar. Res., 65, 345-416, 2007 a.

Buesseler, K. O., Lamborg, C. H., Boyd, P. W., Lam, P. J., Trull, T. W., Bidigare, R. R., Bishop, J. K. B., Casciotti, K. L., Dehairs, F., Elskens, M., Honda, M., Karl, D. M., Siegel, D. A., Silver, M. W., Steinberg, D. K., Valdes, J., Mooy, B. V., and Wilson, S.: Revisiting Carbon Flux Through the Ocean's Twilight Zone, Science, 316, 567-570, doi:10.1126/science.1137959, 2007b.

Buesseler, K. O., McDonnell, A. M. P., Schofield, O. M. E., Steinberg, D. K., and Ducklow, H. W.: High particle export over the continental shelf of the west Antarctic Peninsula, Geophys. Res. Lett., 37, L22606, doi:10.1029/2010GL045448, 2010.

Carlotti, F., Thibault-Botha, D., Nowaczyk, A., and Lefèvre, D.: Zooplankton community structure, biomass and role in carbon fluxes during the second half of a phytoplankton bloom in the eastern sector of the Kerguelen Shelf (January-February 2005), Deep-Sea Res. Pt. II, 55, 720-733, doi:10.1016/j.dsr2.2007.12.010, 2008.

Carlotti, F., Jouandet, M.-P., Nowaczyk, A., Harmelin-Vivien, M., Lefèvre, D., Guillou, G., Zhu, Y., and Zhou, M.: Mesozooplankton structure and functioning during the onset of the Kerguelen phytoplankton bloom during the Keops2 survey, Biogeosciences Discuss., 12, 2381-2427, doi:10.5194/bgd-12-2381-2015, 2015.

Cavan, E. L., Le Moigne, F. A. C., Poulton, A. J., Tarling, G. A., Ward, P., Daniels, C. J., Fragoso, G., and Sanders, R. J.: Zooplankton fecal pellets control the attenuation of particulate organic carbon flux in the Scotia Sea, Southern Ocean, Geophys. Res. Lett., GL062744, doi:10.1002/2014GL062744, 2015.

Checkley, D. M. and Entzeroth, L. C.: Elemental and isotopic fractionation of carbon and nitrogen by marine, planktonic copepods and implications to the marine nitrogen cycle, J. Plankton Res., 7, 553-568, doi:10.1093/plankt/7.4.553, 1985.

Christaki, U., Lefèvre, D., Georges, C., Colombet, J., Catala, P., Courties, C., Sime-Ngando, T., Blain, S., and Obernosterer, I.: Microbial food web dynamics during spring phytoplankton blooms in the naturally iron-fertilized Kerguelen area (Southern Ocean), Biogeosciences, 11, 6739-6753, doi:10.5194/bg-116739-2014, 2014.

Coale, K. H. and Bruland, K. W.: ${ }^{2} 34 \mathrm{Th}$ : 6238U Disequilibria Within the California Current, Limnol. Oceanogr., 30, 22-33, 1985 .

Coale, K. H., Johnson, K. S., Chavez, F. P., Buesseler, K. O., Barber, R. T., Brzezinski, M. A., Cochlan, W. P., Millero, F. J., Falkowski, P. G., Bauer, J. E., Wanninkhof, R. H., Kudela, R. M., Altabet, M. A., Hales, B. E., Takahashi, T., Landry, M. R., Bidigare, R. R., Wang, X., Chase, Z., Strutton, P. G., Friederich, G. E., Gorbunov, M. Y., Lance, V. P., Hilting, A. K., Hiscock, M. R., Demarest, M., Hiscock, W. T., Sullivan, K. F., Tanner, S. J., Gordon, R. M., Hunter, C. N., Elrod, V. A., Fitzwater, S. E., 
Jones, J. L., Tozzi, S., Koblizek, M., Roberts, A. E., Herndon, J., Brewster, J., Ladizinsky, N., Smith, G., Cooper, D., Timothy, D., Brown, S. L., Selph, K. E., Sheridan, C. C., Twining, B. S., and Johnson, Z. I.: Southern Ocean Iron Enrichment Experiment: Carbon Cycling in High- and Low-Si Waters, Science, 304, 408414, doi:10.1126/science.1089778, 2004.

Coppola, L., Roy-Barman, M., Wassmann, P., Mulsow, S., and Jeandel, C.: Calibration of sediment traps and particulate organic carbon export using ${ }^{234} \mathrm{Th}$ in the Barents Sea, Mar. Chem., 80, 11-26, doi:10.1016/S0304-4203(02)00071-3, 2002.

Davison, P. C., Checkley Jr., D. M., Koslow, J. A., and Barlow, J.: Carbon export mediated by mesopelagic fishes in the northeast Pacific Ocean, Prog. Oceanogr., 116, 14-30, doi:10.1016/j.pocean.2013.05.013, 2013.

De Baar, H. J. W., Buma, A. G. J., Nolting, R. F., Cadée, G. C., Jacques, G., and Tréguer, P.: On iron limitation of the Southern Ocean: experimental observations in the Weddell and Scotia Seas, Mar. Ecol.-Prog. Ser. 65, 105-122, doi:10.3354/meps065105, 1990.

De Baar, H. J. W., Boyd, P. W., Coale, K. H., Landry, M. R., Tsuda, A., Assmy, P., Bakker, D. C. E., Bozec, Y., Barber, R. T., Brzezinski, M. A., Buesseler, K. O., Boyé, M., Croot, P. L., Gervais, F., Gorbunov, M. Y., Harrison, P. J., Hiscock, W. T., Laan, P., Lancelot, C., Law, C. S., Levasseur, M., Marchetti, A., Millero, F. J., Nishioka, J., Nojiri, Y., van Oijen, T., Riebesell, U., Rijkenberg, M. J. A., Saito, H., Takeda, S., Timmermans, K. R., Veldhuis, M. J. W., Waite, A. M., and Wong, C.-S.: Synthesis of iron fertilization experiments: From the Iron Age in the Age of Enlightenment, J. Geophys. Res.-Oceans, 110, C09S16, doi:10.1029/2004JC002601, 2005.

Dilling, L. and Alldredge, A. L.: Fragmentation of marine snow by swimming macrozooplankton: A new process impacting carbon cycling in the sea, Deep-Sea Res. Pt. I, 47, 1227-1245, doi:10.1016/S0967-0637(99)00105-3, 2000.

Dunne, J. P., Sarmiento, J. L., and Gnanadesikan, A.: A synthesis of global particle export from the surface ocean and cycling through the ocean interior and on the seafloor, Glob. Biogeochem. Cy., 21, GB4006, doi:10.1029/2006GB002907, 2007.

Ebersbach, F. and Trull, T. W.: Sinking particle properties from polyacrylamide gels during the KErguelen Ocean and Plateau compared Study (KEOPS): Zooplankton control of carbon export in an area of persistent natural iron inputs in the Southern Ocean, Limnol. Oceanogr., 53, 212-224, doi:10.4319/lo.2008.53.1.0212, 2008.

Ebersbach, F., Trull, T. W., Davies, D. M., and Bray, S. G.P: Controls on mesopelagic particle fluxes in the Sub-Antarctic and Polar Frontal Zones in the Southern Ocean south of Australia in summer-Perspectives from free-drifting sediment traps, DeepSea Res. Pt. II, 58, 2260-2276, doi:10.1016/j.dsr2.2011.05.025, 2011.

Fischer, G., Ratmeyer, V., and Wefer, G.: Organic carbon fluxes in the Atlantic and the Southern Ocean: relationship to primary production compiled from satellite radiometer data, Deep-Sea Res. Pt. II, 47, 1961-1997, doi:10.1016/S0967-0645(00)000138, 2000.

Francois, R., Honjo, S., Krishfield, R., and Manganini, S.: Factors controlling the flux of organic carbon to the bathypelagic zone of the ocean, Glob. Biogeochem. Cy., 16, 1087, doi:10.1029/2001GB001722, 2002.
Gall, M. P., Strzepek, R., Maldonado, M., and Boyd, P. W.: Phytoplankton processes, Part 2: Rates of primary production and factors controlling algal growth during the Southern Ocean Iron RElease Experiment (SOIREE), Deep-Sea Res. Pt. II, The Southern Ocean Iron Release Experiment (SOIREE), 48, 2571-2590, doi:10.1016/S0967-0645(01)00009-1, 2001.

Gehlen, M., Bopp, L., Emprin, N., Aumont, O., Heinze, C., and Ragueneau, O.: Reconciling surface ocean productivity, export fluxes and sediment composition in a global biogeochemical ocean model, Biogeosciences, 3, 521-537, doi:10.5194/bg-3521-2006, 2006.

Gerber, R. P. and Gerber, M. B.: Ingestion of natural particulate organic matter and subsequent assimilation, respiration and growth by tropical lagoon zooplankton, Mar. Biol., 52, 33-43, doi:10.1007/BF00386855, 1979.

Giering, S. L. C., Sanders, R., Lampitt, R. S., Anderson, T. R., Tamburini, C., Boutrif, M., Zubkov, M. V., Marsay, C. M., Henson, S. A., Saw, K., Cook, K., and Mayor, D. J..: Reconciliation of the carbon budget in the ocean/'s twilight zone, Nature, 507, 480483, doi:10.1038/nature13123, 2014.

Gilman, D. L., Fuglister, F. J., and Mitchell, J. M.: On the Power Spectrum of "Red Noise.", J. Atmospheric Sci., 20, 182-184, doi:10.1175/1520-0469(1963)020<0182:OTPSON>2.0.CO;2, 1963.

Gordon, H. R. and McCluney, W. R.: Estimation of the depth of sunlight penetration in the sea for remote sensing, Appl. Opt., 14, 413-416, 1975.

Gruber, N., Gloor, M., Mikaloff Fletcher, S. E., Doney, S. C., Dutkiewicz, S., Follows, M. J., Gerber, M., Jacobson, A. R., Joos, F., Lindsay, K., Menemenlis, D., Mouchet, A., Müller, S. A., Sarmiento, J. L., and Takahashi, T.: Oceanic sources, sinks, and transport of atmospheric $\mathrm{CO}_{2}$, Glob. Biogeochem. Cy., 23, GB1005, doi:10.1029/2008GB003349, 2009.

Guidi, L., Jackson, G. A., Stemmann, L., Miquel, J. C., Picheral, M., and Gorsky, G.: Relationship between particle size distribution and flux in the mesopelagic zone, Deep-Sea Res. Pt. I, 55, 13641374, doi:10.1016/j.dsr.2008.05.014, 2008.

Gustafsson, O., Andersson, P., Roos, P., Kukulska, Z., Broman, D., Larsson, U., Hajdu, S., and Ingri, J.: Evaluation of the collection efficiency of upper ocean sub-photic-layer sediment traps: A 24-month in situ calibration in the open Baltic Sea using ${ }^{234} \mathrm{Th}$, Limnol. Oceanogr.-Methods, 2, 62-74, doi:10.4319/lom.2004.2.62, 2004.

Hawley, N.: Flow in Cylindrical Sediment Traps, J. Great Lakes Res., 14, 76-88, doi:10.1016/S0380-1330(88)71534-8, 1988.

Henson, S. A., Sanders, R., Madsen, E., Morris, P. J., Le Moigne, F., and Quartly, G. D.: A reduced estimate of the strength of the ocean's biological carbon pump, Geophys. Res. Lett., 38, L04606, doi:10.1029/2011GL046735, 2011.

Henson, S. A., Sanders, R., and Madsen, E.: Global patterns in efficiency of particulate organic carbon export and transfer to the deep ocean, Glob. Biogeochem. Cy., 26, GB1028, doi:10.1029/2011GB004099, 2012.

Henson, S. A., Yool, A., and Sanders, R.: Variability in efficiency of particulate organic carbon export: A model study, Glob. Biogeochem. Cy., 29, GB4965, doi:10.1002/2014GB004965, 2014.

Hiscock, W. T. and Millero, F. J.: Nutrient and carbon parameters during the Southern Ocean iron experiment (SOFeX), Deep-Sea Res. Pt. I, 52, 2086-2108, doi:10.1016/j.dsr.2005.06.010, 2005. 
Honjo, S., Francois, R., Manganini, S., Dymond, J., and Collier, R.: Particle fluxes to the interior of the Southern Ocean in the Western Pacific sector along $170^{\circ} \mathrm{W}$, Deep-Sea Res. Pt. II, 47, 3521-3548, doi:10.1016/S0967-0645(00)00077-1, 2000.

Honjo, S., Manganini, S. J., Krishfield, R. A., and Francois, R.: Particulate organic carbon fluxes to the ocean interior and factors controlling the biological pump: A synthesis of global sediment trap programs since 1983, Prog. Oceanogr., 76, 217-285, doi:10.1016/j.pocean.2007.11.003, 2008.

Hudson, J. M., Steinberg, D. K., Sutton, T. T., Graves, J. E., and Latour, R. J.: Myctophid feeding ecology and carbon transport along the northern Mid-Atlantic Ridge, Deep-Sea Res. Pt. I, 93, 104-116, doi:10.1016/j.dsr.2014.07.002, 2014.

Jacquet, S. H. M., Dehairs, F., Savoye, N., Obernosterer, I., Christaki, U., Monnin, C., and Cardinal, D.: Mesopelagic organic carbon remineralization in the Kerguelen Plateau region tracked by biogenic particulate Ba, Deep-Sea Res. Pt. II, 55, 868-879, doi:10.1016/j.dsr2.2007.12.038, 2008.

JGOFS: Sediment Trap Methods, in: Protocols for the Joint Global Ocean Flux Study (JGOFS) Core Measurements, Intergovernmental Oceanographic Commission, Scientific Committee on Oceanic Research Manual and Guides, UNESCO, 157-164, 1994.

Jouandet, M. P., Blain, S., Metzl, N., Brunet, C., Trull, T. W., and Obernosterer, I.: A seasonal carbon budget for a naturally iron-fertilized bloom over the Kerguelen Plateau in the Southern Ocean, Deep-Sea Res. Pt. II, KEOPS: Kerguelen Ocean and Plateau compared Study, 55, 856-867, doi:10.1016/j.dsr2.2007.12.037, 2008.

Jouandet, M.-P., Trull, T. W., Guidi, L., Picheral, M., Ebersbach, F., Stemmann, L., and Blain, S.: Optical imaging of mesopelagic particles indicates deep carbon flux beneath a natural ironfertilized bloom in the Southern Ocean, Limnol. Oceanogr., 56, 1130-1140, doi:10.4319/lo.2011.56.3.1130, 2011.

Jouandet, M.-P., Jackson, G. A., Carlotti, F., Picheral, M., Stemmann, L., and Blain, S.: Rapid formation of large aggregates during the spring bloom of Kerguelen Island: observations and model comparisons, Biogeosciences, 11, 4393-4406, doi:10.5194/bg-11-4393-2014, 2014.

Karleskind, P., Lévy, M., and Memery, L.: Subduction of carbon, nitrogen, and oxygen in the northeast Atlantic, J. Geophys. Res.Oceans, 116, C02025, doi:10.1029/2010JC006446, 2011.

Kohfeld, K. E., Quéré, C. L., Harrison, S. P., and Anderson, R. F.: Role of Marine Biology in Glacial-Interglacial $\mathrm{CO}_{2}$ Cycles, Science, 308, 74-78, doi:10.1126/science.1105375, 2005.

Korb, R. E. and Whitehouse, M.: Contrasting primary production regimes around South Georgia, Southern Ocean: large blooms versus high nutrient, low chlorophyll waters, Deep-Sea Res. Pt. I, 51, 721-738, doi:10.1016/j.dsr.2004.02.006, 2004.

Koubbi, P., Duhamel, G., and Hebert, C.: Seasonal relative abundance of fish larvae inshore at Îles Kerguelen, Southern Ocean. Antarct. Sci., 13, 385-392, doi:10.1017/S0954102001000542, 2001

Koubbi, P., Ibanez, F., and Duhamel, G.: Environmental influences on spatio-temporal oceanic distribution of ichthyoplankton around the Kerguelen Islands (Southern Ocean), Mar. Ecol.Prog. Ser., 72, 225-238, 1991.
Lam, P. J. and Bishop, J. K. B.: High biomass, low export regimes in the Southern Ocean, Deep-Sea Res. Pt. II, 54, 601-638, doi:10.1016/j.dsr2.2007.01.013, 2007.

Lam, P. J., Doney, S. C., and Bishop, J. K. B.: The dynamic ocean biological pump: Insights from a global compilation of particulate organic carbon, $\mathrm{CaCO}_{3}$, and opal concentration profiles from the mesopelagic, Glob. Biogeochem. Cy., 25, GB3009, doi:10.1029/2010GB003868, 2011.

Lampitt, R. S. and Antia, A. N.: Particle flux in deep seas: regional characteristics and temporal variability, Deep-Sea Res. Pt. I, 44, 1377-1403, doi:10.1016/S0967-0637(97)00020-4, 1997.

Lampitt, R. S., Boorman, B., Brown, L., Lucas, M., Salter, I., Sanders, R., Saw, K., Seeyave, S., Thomalla, S. J., and Turnewitsch, R.: Particle export from the euphotic zone: Estimates using a novel drifting sediment trap, 234Th and new production, Deep-Sea Res. Pt. I, 55, 1484-1502, doi:10.1016/j.dsr.2008.07.002, 2008.

Landry, M. R., Constantinou, J., Latasa, M., Brown, S. L., Bidigare, R. R., and Ondrusek, M. E.: Biological response to iron fertilization in the eastern equatorial Pacific (IronEx II), III. Dynamics of phytoplankton growth and microzooplankton grazing, Mar Ecol.-Prog. Ser., 201, 57-72, doi:10.3354/meps201057, 2000.

Laurenceau-Cornec, E. C., Trull, T. W., Davies, D. M., Bray, S. G., Doran, J., P lanchon, F., Carlotti, F., Jouandet, M.-P., Cavagna, A.-J., Waite, A. M., and Blain, S.: The relative importance of phytoplankton aggregates and zooplankton fecal pellets to carbon export: insights from free-drifting sediment trap deployments in naturally iron-fertilised waters near the Kerguelen Plateau, Biogeosciences, 12, 1007-1027, doi:10.5194/bg-121007-2015, 2015.

Laws, E. A., Falkowski, P. G., Smith, W. O., Ducklow, H., and McCarthy, J. J.: Temperature effects on export production in the open ocean, Glob. Biogeochem. Cy. 14, 1231-1246, doi:10.1029/1999GB001229, 2000.

Laws, E. A., D'Sa, E., and Naik, P.: Simple equations to estimate ratios of new or export production to total production from satellite-derived estimates of sea surface temperature and primary production, Limnol. Oceanogr.-Methods, 593-601, doi:10.4319/lom.2011.9.593, 2011.

Lefèvre, D., Guigue, C., and Obernosterer, I.: The metabolic balance at two contrasting sites in the Southern Ocean: The ironfertilized Kerguelen area and HNLC waters, Deep-Sea Res. Pt. II, KEOPS: Kerguelen Ocean and Plateau compared Study, 55, 766-776, doi:10.1016/j.dsr2.2007.12.006, 2008.

Le Moigne, F. A. C., Sanders, R. J., Villa-Alfageme, M., Martin, A. P., Pabortsava, K., Planquette, H., Morris, P. J., and Thomalla, S. J.: On the proportion of ballast versus non-ballast associated carbon export in the surface ocean, Geophys. Res. Lett., 39, L15610, doi:10.1029/2012GL052980, 2012.

Lenton, A., Tilbrook, B., Law, R. M., Bakker, D., Doney, S. C., Gruber, N., Ishii, M., Hoppema, M., Lovenduski, N. S., Matear, R. J., McNeil, B. I., Metzl, N., Mikaloff Fletcher, S. E., Monteiro, P. M. S., Rödenbeck, C., Sweeney, C., and Takahashi, T.: Seaair $\mathrm{CO}_{2}$ fluxes in the Southern Ocean for the period 1990-2009, Biogeosciences, 10, 4037-4054, doi:10.5194/bg-10-4037-2013, 2013.

Le Quéré, C., Andres, R. J., Boden, T., Conway, T., Houghton, R. A., House, J. I., Marland, G., Peters, G. P., van der Werf, G. R., Ahlström, A., Andrew, R. M., Bopp, L., Canadell, J. G., Ciais, 
P., Doney, S. C., Enright, C., Friedlingstein, P., Huntingford, C., Jain, A. K., Jourdain, C., Kato, E., Keeling, R. F., Klein Goldewijk, K., Levis, S., Levy, P., Lomas, M., Poulter, B., Raupach, M. R., Schwinger, J., Sitch, S., Stocker, B. D., Viovy, N., Zaehle, S., and Zeng, N.: The global carbon budget 1959-2011, Earth Syst. Sci. Data, 5, 165-185, doi:10.5194/essd-5-165-2013, 2013.

Levy, M., Bopp, L., Karleskind, P., Resplandy, L., Ethe, C., and Pinsard, F.: Physical pathways for carbon transfers between the surface mixed layer and the ocean interior, Glob. Biogeochem. Cy., 27, 1001-1012, doi:10.1002/gbc.20092, 2013.

Lima, I. D., Lam, P. J., and Doney, S. C.: Dynamics of particulate organic carbon flux in a global ocean model, Biogeosciences, 11, 1177-1198, doi:10.5194/bg-11-1177-2014, 2014.

Lutz, M. J., Caldeira, K., Dunbar, R. B., and Behrenfeld, M. J.: Seasonal rhythms of net primary production and particulate organic carbon flux to depth describe the efficiency of biological pump in the global ocean, J. Geophys. Res.-Oceans, 112, C10011, doi:10.1029/2006JC003706, 2007.

Maiti, K., Charette, M. A., Buesseler, K. O., and Kahru, M.: An inverse relationship between production and export efficiency in the Southern Ocean, Geophys. Res. Lett., 40, 1557-1561, doi:10.1002/grl.50219, 2013.

Manno, C., Stowasser, G., Enderlein, P., Fielding, S., and Tarling, G. A.: The contribution of zooplankton faecal pellets to deep-carbon transport in the Scotia Sea (Southern Ocean), Biogeosciences, 12, 1955-1965, doi:10.5194/bg-12-1955-2015, 2015.

Maraldi, C., Mongin, M., Coleman, R., and Testut, L.: The influence of lateral mixing on a phytoplankton bloom: Distribution in the Kerguelen Plateau region, Deep-Sea Res. Pt. I, 56, 963-973, doi:10.1016/j.dsr.2008.12.018, 2009.

Maraldi, C., Lyard, F., Testut, L., and Coleman, R.: Energetics of internal tides around the Kerguelen Plateau from modeling and altimetry, J. Geophys. Res.-Oceans, 116, C06004, doi:10.1029/2010JC006515, 2011.

Maritorena, S. and Siegel, D. A.: Consistent merging of satellite ocean color data sets using a bio-optical model, Remote Sens. Environ., 94, 429-440, doi:10.1016/j.rse.2004.08.014, 2005.

Martin, J. H.: Glacial-interglacial $\mathrm{CO}_{2}$ change: The Iron Hypothesis, Paleoceanography, 5, 1-13, doi:10.1029/PA005i001p00001, 1990.

Martin, J. H., Knauer, G. A., Karl, D. M., and Broenkow, W. W.: VERTEX: carbon cycling in the northeast Pacific, Deep-Sea Res. Pt. I, 34, 267-285, doi:10.1016/0198-0149(87)90086-0, 1987.

Martin, P., van der Loeff, M. R., Cassar, N., Vandromme, P., d' Ovidio, F., Stemmann, L., Rengarajan, R., Soares, M., González, H. E., Ebersbach, F., Lampitt, R. S., Sanders, R., Barnett, B. A., Smetacek, V., and Naqvi, S. W. A.: Iron fertilization enhanced net community production but not downward particle flux during the Southern Ocean iron fertilization experiment LOHAFEX, Glob. Biogeochem. Cy., 27, 871-881, doi:10.1002/gbc.20077, 2013.

Matsuno, K., Yamaguchi, A., Fujiwara, A., Onodera, J., Watanabe, E., Imai, I., Chiba, S., Harada, N., and Kikuchi, T.: Seasonal changes in mesozooplankton swimmers collected by sediment trap moored at a single station on the Northwind Abyssal Plain in the western Arctic Ocean, J. Plankton Res., 36, 490-502, doi:10.1093/plankt/fbt092, 2014.

Measures, C. I., Brown, M. T., Selph, K. E., Apprill, A., Zhou, M., Hatta, M., and Hiscock, W. T.: The influence of shelf processes in delivering dissolved iron to the HNLC waters of the
Drake Passage, Antarctica, Deep-Sea Res. Pt. II, 90, 77-88, doi:10.1016/j.dsr2.2012.11.004, 2013.

Metzl, N., Brunet, C., Jabaud-Jan, A., Poisson, A., and Schauer, B.: Summer and winter air-sea $\mathrm{CO}_{2}$ fluxes in the Southern Ocean, Deep-Sea Res. Pt. I, 53, 1548-1563, doi:10.1016/j.dsr.2006.07.006, 2006.

Moore, J. K., Doney, S. C., and Lindsay, K.: Upper ocean ecosystem dynamics and iron cycling in a global threedimensional model, Glob. Biogeochem. Cy., 18, GB4028, doi:10.1029/2004GB002220, 2004.

Morales, C. E.: Carbon and nitrogen content of copepod faecal pellets: effect of food concentration and feeding behaviour, Mar. Ecol.-Prog. Ser., 36, 107-114, 1987.

Obernosterer, I., Christaki, U., Lefèvre, D., Catala, P., Van Wambeke, F., and Lebaron, P.: Rapid bacterial mineralization of organic carbon produced during a phytoplankton bloom induced by natural iron fertilization in the Southern Ocean, Deep-Sea Res. Pt. II, 55, 777-789, doi:10.1016/j.dsr2.2007.12.005, 2008.

O’Neill, L. P., Benitez-Nelson, C. R., Styles, R. M., Tappa, E., and Thunell, R. C.: Diagenetic effects on particulate phosphorus samples collected using formalin poisoned sediment traps, Limnol. Oceanogr.-Methods, 3, 308-317, doi:10.4319/lom.2005.3.308, 2005.

Park, Y.-H., Charriaud, E., Pino, D. R., and Jeandel, C.: Seasonal and interannual variability of the mixed layer properties and steric height at station KERFIX, southwest of Kerguelen, J. Mar. Syst., 17, 571-586, doi:10.1016/S0924-7963(98)00065-7, 1998.

Park, Y.-H., Fuda, J.-L., Durand, I., and Naveira Garabato, A. C.: Internal tides and vertical mixing over the Kerguelen Plateau, Deep-Sea Res. Pt. II, 55, 582-593, doi:10.1016/j.dsr2.2007.12.027, 2008a.

Park, Y.-H., Roquet, F., Durand, I., and Fuda, J.-L.: Large-scale circulation over and around the Northern Kerguelen Plateau, DeepSea Res. Pt. II, 55, 566-581, doi:10.1016/j.dsr2.2007.12.030, 2008b.

Peterson, M. L., Wakeham, S. G., Lee, C., Askea, M. A., and Miquel, J. C.: Novel techniques for collection of sinking particles in the ocean and determining their settling rates, Limnol. Oceanogr.-Methods, 3, 520-532, doi:10.4319/lom.2005.3.520, 2005.

Picheral, M., Guidi, L., Stemmann, L., Karl, D. M., Iddaoud, G., and Gorsky, G.: The Underwater Vision Profiler 5: An advanced instrument for high spatial resolution studies of particle size spectra and zooplankton, Limnol. Oceanogr.-Methods, 8, 462-473, doi:10.4319/lom.2010.8.462, 2010.

Planchon, F., Ballas, D., Cavagna, A.-J., Bowie, A. R., Davies, D., Trull, T., Laurenceau, E., Van Der Merwe, P., and Dehairs, F.: Carbon export in the naturally iron-fertilized Kerguelen area of the Southern Ocean based on the 234Th approach, Biogeosciences Discuss., 11, 15991-16032, doi:10.5194/bgd11-15991-2014, 2014.

Pollard, R., Sanders, R., Lucas, M., and Statham, P.: The Crozet Natural Iron Bloom and Export Experiment (CROZEX), DeepSea Res. Pt. II, 54, 1905-1914, doi:10.1016/j.dsr2.2007.07.023, 2007.

Pollard, R. T., Salter, I., Sanders, R. J., Lucas, M. I., Moore, C. M., Mills, R. A., Statham, P. J., Allen, J. T., Baker, A. R., Bakker, D. C. E., Charette, M. A., Fielding, S., Fones, G. R., French, M., Hickman, A. E., Holland, R. J., Hughes, J. A., Jickells, T. 
D., Lampitt, R. S., Morris, P. J., Nédélec, F. H., Nielsdóttir, M., Planquette, H., Popova, E. E., Poulton, A. J., Read, J. F., Seeyave, S., Smith, T., Stinchcombe, M., Taylor, S., Thomalla, S., Venables, H. J., Williamson, R., and Zubkov, M. V.: Southern Ocean deep-water carbon export enhanced by natural iron fertilization, Nature, 457, 577-580, doi:10.1038/nature07716, 2009.

Rembauville, M., Blain, S., Armand, L., Quéguiner, B., and Salter, I.: Export fluxes in a naturally iron-fertilized area of the Southern Ocean - Part 2: Importance of diatom resting spores and faecal pellets for export, Biogeosciences, 12, 3171-3195, doi:10.5194/bg-12-3171-2015, 2015.

Rigual-Hernández, A. S., Trull, T. W., Bray, S. G., Closset, I., and Armand, L. K.: Seasonal dynamics in diatom and particulate export fluxes to the deep sea in the Australian sector of the southern Antarctic Zone, J. Mar. Syst., 142, 62-74, doi:10.1016/j.jmarsys.2014.10.002, 2015.

Rivkin, R. B. and Legendre, L.: Biogenic carbon cycling in the upper ocean: effects of microbial respiration, Science, 291, 23982400, doi:10.1126/science.291.5512.2398, 2001.

Rynearson, T. A., Richardson, K., Lampitt, R. S., Sieracki, M. E., Poulton, A. J., Lyngsgaard, M. M., and Perry, M. J.: Major contribution of diatom resting spores to vertical flux in the sub-polar North Atlantic, Deep-Sea Res. Pt. I, 82, 60-71, doi:10.1016/j.dsr.2013.07.013, 2013.

Saba, G. K. and Steinberg, D. K.: Abundance, Composition, and Sinking Rates of Fish Fecal Pellets in the Santa Barbara Channel, Sci. Rep., 2, doi:10.1038/srep00716, 2012.

Salter, I., Lampitt, R. S., Sanders, R., Poulton, A., Kemp, A. E. S., Boorman, B., Saw, K., and Pearce, R.: Estimating carbon, silica and diatom export from a naturally fertilised phytoplankton bloom in the Southern Ocean using PELAGRA: A novel drifting sediment trap, Deep-Sea Res. Pt. II, The Crozet Natural Iron Bloom and Export Experiment CROZEX, 54, 2233-2259, doi:10.1016/j.dsr2.2007.06.008, 2007.

Salter, I., Kemp, A. E. S., Lampitt, R. S., and Gledhill, M.: The association between biogenic and inorganic minerals and the amino acid composition of settling particles, Limnol. Oceanogr., 55, 2207-2218, doi:10.4319/lo.2010.55.5.2207, 2010.

Salter, I., Kemp, A. E. S., Moore, C. M., Lampitt, R. S., Wolff, G. A., and Holtvoeth, J.: Diatom resting spore ecology drives enhanced carbon export from a naturally iron-fertilized bloom in the Southern Ocean, Glob. Biogeochem. Cy., 26, GB1014, doi:10.1029/2010GB003977, 2012.

Salter, I., Schiebel, R., Ziveri, P., Movellan, A., Lampitt, R., and Wolff, G. A.: Carbonate counter pump stimulated by natural iron fertilization in the Polar Frontal Zone, Nat. Geosci., 7, 885-889, doi:10.1038/ngeo2285, 2014

Sarmiento, J. L. and Gruber, N.: Ocean Biogeochemical Dynamics, Princeton University Press, Princeton, 2006.

Sarmiento, J. L. and Le Quéré, C.: Oceanic Carbon Dioxide Uptake in a Model of Century-Scale Global Warming, Science, 274, 1346-1350, 1996.

Sarthou, G., Timmermans, K. R., Blain, S., and Tréguer, P.: Growth physiology and fate of diatoms in the ocean: a review, J. Sea Res., Iron Resources and Oceanic Nutrients - Advancement of Global Environmental Simulations, 53, 25-42, doi:10.1016/j.seares.2004.01.007, 2005.

Savoye, N., Benitez-Nelson, C., Burd, A. B., Cochran, J. K., Charette, M., Buesseler, K. O., Jackson, G. A., Roy-Barman, M.,
Schmidt, S., and Elskens, M.: ${ }^{234}$ Th sorption and export models in the water column: A review, Mar. Chem., 100, 234-249, doi:10.1016/j.marchem.2005.10.014, 2006.

Savoye, N., Trull, T. W., Jacquet, S. H. M., Navez, J., and Dehairs, F.: 234Th-based export fluxes during a natural iron fertilization experiment in the Southern Ocean (KEOPS), Deep-Sea Res. Pt. II, KEOPS: Kerguelen Ocean and Plateau compared Study, 55, 841-855, doi:10.1016/j.dsr2.2007.12.036, 2008.

Schlitzer, R.: Export production in the Equatorial and North Pacific derived from dissolved oxygen, nutrient and carbon data, J. Oceanogr., 60, 53-62, 2004.

Schulz, M. and Mudelsee, M.: REDFIT: estimating red-noise spectra directly from unevenly spaced paleoclimatic time series, Comput. Geosci., 28, 421-426, doi:10.1016/S00983004(01)00044-9, 2002.

Seeyave, S., Lucas, M. I., Moore, C. M., and Poulton, A. J.: Phytoplankton productivity and community structure in the vicinity of the Crozet Plateau during austral summer 2004/2005, The Crozet Natural Iron Bloom and Export Experiment CROZEX, DeepSea Res. Pt. II, 54, 2020-2044, doi:10.1016/j.dsr2.2007.06.010, 2007.

Smetacek, V., Assmy, P., and Henjes, J.: The role of grazing in structuring Southern Ocean pelagic ecosystems and biogeochemical cycles, Antarct. Sci., 16, 541-558, doi:10.1017/S0954102004002317, 2004.

Smith, R. C:. Remote sensing and depth distribution of ocean chlorophyll, Mar. Ecol.-Prog. Ser., 5, 359-361, 1981.

Tarling, G. A., Ward, P., Atkinson, A., Collins, M. A., and Murphy, E. J.: DISCOVERY 2010: Spatial and temporal variability in a dynamic polar ecosystem, Deep-Sea Res. Pt. II, 59-60, 1-13, doi:10.1016/j.dsr2.2011.10.001, 2012.

Trull, T. W., Bray, S. G., Buesseler, K. O., Lamborg, C. H., Manganini, S., Moy, C., and Valdes, J.: In situ measurement of mesopelagic particle sinking rates and the control of carbon transfer to the ocean interior during the Vertical Flux in the Global Ocean (VERTIGO) voyages in the North Pacific, DeepSea Res. Pt. II, 55, 1684-1695, doi:10.1016/j.dsr2.2008.04.021, 2008a.

Trull, T. W., Davies, D., and Casciotti, K.: Insights into nutrient assimilation and export in naturally iron-fertilized waters of the Southern Ocean from nitrogen, carbon and oxygen isotopes, Deep-Sea Res. Pt. II, 55, 820-840, doi:10.1016/j.dsr2.2007.12.035, 2008b.

Tsuda, A., Takeda, S., Saito, H., Nishioka, J., Kudo, I., Nojiri, Y., Suzuki, K., Uematsu, M., Wells, M.L., Tsumune, D., Yoshimura, T., Aono, T., Aramaki, T., Cochlan, W.P., Hayakawa, M., Imai, K., Isada, T., Iwamoto, Y., Johnson, W. K., Kameyama, S., Kato, S., Kiyosawa, H., Kondo, Y., Levasseur, M., Machida, R. J., Nagao, I., Nakagawa, F., Nakanishi, T., Nakatsuka, S., Narita, A., Noiri, Y., Obata, H., Ogawa, H., Oguma, K., Ono, T., Sakuragi, T., Sasakawa, M., Sato, M., Shimamoto, A., Takata, H., Trick, C.G., Watanabe, Y. W., Wong, C. S., and Yoshie, N.: Evidence for the grazing hypothesis: Grazing reduces phytoplankton responses of the HNLC ecosystem to iron enrichment in the western subarctic pacific (SEEDS II), J. Oceanogr., 63, 983-994, doi:10.1007/s10872-007-0082-x, 2007.

Uitz, J., Claustre, H., Griffiths, F. B., Ras, J., Garcia, N., and Sandroni, V.: A phytoplankton class-specific primary production model applied to the Kerguelen Islands region (Southern Ocean), 
Deep-Sea Res. Pt. I, 56, 541-560, doi:10.1016/j.dsr.2008.11.006, 2009.

Villareal, T. A., Adornato, L., Wilson, C., and Schoenbaechler, C. A.: Summer blooms of diatom-diazotroph assemblages and surface chlorophyll in the North Pacific gyre: A disconnect, J. Geophys. Res.-Oceans, 116, C03001, doi:10.1029/2010JC006268, 2011.
Volk, T. and Hoffert, M. I.: Ocean carbon pumps: Analysis of relative strengths and efficiencies in ocean-driven atmospheric $\mathrm{CO}_{2}$ changes, in: Geophysical Monograph Series, edited by:: Sundquist, E. T. and Broecker, W. S., American Geophysical Union, Washington, D. C., 99-110, 1985. 